PONTIFÍCIA UNIVERSIDADE CATÓLICA do RIO dE JANEIRO

\title{
Responsabilidade Socioambiental Empresarial ou Ação Social Privada? A gestão e as práticas da Vale
}

Catarina Fortes Brandão

Trabalho de Conclusão de Curso

Centro de CIÊNCIAS SOCIAIS - CCS

DePARTAMENTO de AdMINISTRAÇÃo

Graduação em Administração de Empresas 
Catarina Fortes Brandão

Responsabilidade Socioambiental Empresarial ou Ação Social Privada? A gestão e as práticas da Vale

Trabalho de Conclusão de Curso

Trabalho de Conclusão de Curso, apresentado ao programa de graduação em Administração da PUC-Rio como requisito parcial para a obtenção do título de graduação em Administração.

Orientador: Ciro Torres 


\section{Resumo}

Brandão, Catarina. Responsabilidade Socioambiental Empresarial ou Ação Social Privada? A gestão e as práticas da Vale. Rio de Janeiro, 2021. Número de páginas p.65 Trabalho de Conclusão de Curso - Departamento de Administração. Pontifícia Universidade Católica do Rio de Janeiro.

O presente trabalho aborda a responsabilidade socioambiental e a sustentabilidade e seus conceitos aplicados na gestão das empresas, assim como a Responsabilidade Social Ambiental, a Ação Social Privada e a ESG, buscando entender e analisando como, de fato, uma empresa se posiciona e coloca em prática estes conceitos e ferramentas de gestão. Para isso, foram revistos diferentes conceitos: Responsabilidade Socioambiental, Sustentabilidade GreenWashing e Ação Social Privada, entre outros. A partir deste objetivo, analisamos a aplicação desses conceitos nas práticas da empresa Vale, para entender como é a sua relação com a sustentabilidade e quais suas principais motivações para reparar os danos socioambientais causados no passado. Por fim, após essa análise, são feitas sugestões de melhoria para a empresa em questão, visando um caminho em prol de um mundo empresarial mais sustentável e responsável, servindo também de como possível referência para a gestão interna e externa da responsabilidade socioambiental de outras empresas.

\section{Palavras-chave}

Responsabilidade Socio Ambiental. Ação Social Privada. Filantropia. Tripé da Sustentabilidade. Greenwashing. Problemas de Gestão. Empresa Vale. Insustentabilidade. 


\section{Abstract}

Brandão, Catarina. Socio-Environmental Corporate Responsibility or Private Social Action? Vale management and practices. Rio de Janeiro, 2021. Número de páginas p.65 Trabalho de Conclusão de Curso - Departamento de Administração. Pontifícia Universidade Católica do Rio de Janeiro.

This paper considers socio-environmental responsibility and sustainability and the application of these concepts to corporate management, such as environmental social responsibility, private social action, and ESG, seeking to analyze and understand how a company actually stands and deploys these concepts and management tools. To that end, a number of concepts were reviewed: socio-environmental responsibility, sustainability, greenwashing, and private social action, among others. Then, the application of those concepts were analyzed in the practices of Vale mining company, in order to understand how their relationship to sustainability works and what their main motives are to remedy past socio-environmental damage wreaked. Lastly, that analysis yielded proposals for improvement for that company, looking for a path leading to a more sustainable and responsible corporate world that could also offer guidance for internal and external governance of socio-environmental responsibility at other corporations.

Keywords

Socio-environmental Responsibility; Private Social Action; Sustainability Tripod; Greenwashing; Management Issues; Vale Mining Company; Non-Sustainability. 


\section{Sumário}

1. Introdução 1

1.1. Objetivo 3

1.2. Delimitação 3

1.3. Relevância 4

2. Referencial Teórico 5

2.1. Responsabilidade Socioambiental 5

2.2. Ação Social Privada 9

2.3. Ferramentas da Responsabilidade Social Ambiental 13

2.3.1. Pacto Global 13

2.3.1.1. Direitos Humanos 14

$\begin{array}{ll}\text { 2.3.1.2. Trabalho } & 14\end{array}$

2.3.1.3. Meio Ambiente 14

2.3.1.4. Contra a Corrupção 14

2.3.2. Balanço Social $\quad 15$

2.3.3. Global Reporting Initiative 16

$\begin{array}{ll}\text { 2.3.4. SA8000 } & 18\end{array}$

2.4. Triple Bottom Line 20

2.5. Greenwashing 22

2.6. ESG (Environmental, Social and Governance) 24

3. Metodologia 27

3.1. Etapas do trabalho 27

3.2. Método de pesquisa aplicado 28

4 Empresa Vale $\quad 29$

4.1. A empresa 29

4.2. Práticas Sustentáveis Positivas 31

4.2.1. Medidas de Redução de Consumo e Reutilização da Água 31

4.2.2. Ações durante a pandemia 33

4.2.3. Conservação Ambiental 34 
4.3. Problemas de Gestão 37

4.3.1. Rompimento das barragens de Mariana e Brumadinho 37

4.3.2. Reassentamentos das comunidades em Tete 42

4.3.3. Práticas Desleais com trabalhadores durante o Coronavírus 44

4.3.4. Relatório de Insustentabilidade 46

4.4. O uso das ferramentas de Responsabilidade Social Empresarial $\quad 47$

4.4.1. Pacto Global 47

4.4.2. Balanço Social 50

4.4.3. Global Reporting Initiative (GRI) 51

4.4.4. SA8000 52

5 Análise $\quad 54$

5.1. Vale e a Responsabilidade Socioambiental 54

5.2. Greenwashing e ESG 56

5.3. Tripé da Sustentabilidade $\quad 57$

5.4. Ferramentas da RSE 58

6 Conclusões e Sugestões 59

6.1. Reparação de danos 59

6.2. Gestão de Risco 60

6.3. Gestão de pessoas 61

6.4. Ação Social Privada 62

$\begin{array}{ll}\text { Referências Bibliográficas } & 63\end{array}$

\section{Lista de Figuras}

Figura 1 - Pirâmide de Carroll

Figura 2 - Tripé da Sustentabilidade 


\section{Introdução}

Quando se trata de sustentabilidade, estamos falando não apenas da relação humana com o próprio ambiente, mas também da relação intrapessoal, do homem com ele mesmo. Este termo, assim, alude não somente à certas atividades prescritas para o meio ambiente, mas também à posturas éticas e conscientes nas interações do homem com o mundo e consigo próprio. Por isso mesmo, Machado Filho ressalta que "a evolução institucional ocorre também no sentido de que as pessoas estão mais conscientes dos seus direitos e deveres sociais, menos tolerantes a práticas abusivas e antiéticas" (MACHADO FILHO, 2006, p. 16).

A preocupação com esse termo virou uma discussão ampla, nos 4 cantos do mundo, e para alcançar a harmonia na vida humana, Nascimento indica que precisamos de:

"um sistema político que garanta a participação da população nos processos decisórios, um sistema econômico capaz de gerar excedentes, um sistema social que possa resolver tensões causadas por um desenvolvimento não equilibrado, um sistema de produção que preserve a base ecológica do desenvolvimento, um sistema tecnológico

que busque constantemente novas soluções, um sistema internacional que estimule padrões sustentáveis de comércio e financiamento, e por fim, um sistema administrativo capaz de se autocorrigir." (NASCIMENTO, 2012, p. 36).

Em 1962, em um cenário mundial no qual se difundiam os estudos sobre o homem, a antropologia, começou também a se pensar sobre a interação daquele com a natureza, e sobre os impactos que a ação humana e suas atividades geram no meio ambiente. Nesse contexto, se dá a publicação do livro "A Primavera Silenciosa", de Raquel Carson, que pode ser considerado um marco da gestão socioambiental pois reflete sobre o bem-estar social, o relacionamento com a natureza, além da economia, ampliando a conscientização a respeito dos males causados ao ambiente, abrindo, portanto, espaço para essa discussão em outros níveis.

Dez anos depois, em 1972, é realizada a primeira conferência nacional sobre o homem e o meio ambiente, a Conferência de Estocolmo, visando diminuir 
o uso dos recursos naturais pela indústria, concebendo que a natureza pode ser esgotável.

Em 1987, surge o Relatório da Comissão Mundial sobre o Meio Ambiente e Desenvolvimento (CIMAD) também conhecido como Relatório Brundtland, estabelecido pela Assembleia Geral das Nações Unidas,

Com o título de Nosso Futuro Comum busca tornar global o conceito de Desenvolvimento Sustentável, trazendo responsabilidade para os países pelos danos ambientalmente causados, e um alerta sobre a importância de mudar os padrões de consumo e desenvolvimento desenfreados, preconizando um progresso mais consciente.

No Rio de Janeiro, em 1992, 20 anos depois da primeira conferência, é realizada a Eco-92, mais uma vez um Fórum Global, que busca definir e incentivar iniciativas que ajudassem a alcançar a meta do Desenvolvimento Sustentável no século XXI. Dez anos depois, a Conferência RIO+10 organizada pela Organização das Nações Unidas (ONU), reunindo 189 países e diversas ONGs em Johanesburgo, tinha como intuito de avaliar o sucesso e resultados da Eco-92.

Como se pode ver, a sustentabilidade não é um conceito novo, tratando-se, segundo Barbieri (2007), de uma preocupação com o meio ambiente que não pode ser considerada recente, mas foi apenas nas últimas décadas do século $X X$ que ela de fato passou a fazer parte de agendas de governos e da sociedade como um todo.

Tendo em vista esse cenário, no meio empresarial, investir em sustentabilidade não é mais apenas um fator de vantagem competitiva para as empresas, mas sim um quesito de sobrevivência no mercado. 


\subsection{Objetivo}

Tendo em vista o cenário atual da sustentabilidade no mundo, muitas corporações estão crescendo e aderindo às práticas sustentáveis interna e externamente.

Esse trabalho busca, como objetivo, entender e analisar as práticas da empresa Vale, e como elas se enquadram na política sustentável, examinando se são efetivamente ações de responsabilidade socioambiental pelo interesse da empresa em usar seus recursos para minimizar os impactos do homem, ou se, considerando seus diversos problemas de gestão, se seriam uma forma de engajar a empresa no mercado com uma imagem positiva, desviando a atenção de seus escândalos.

Além disso, o objetivo secundário do trabalho busca sugerir melhorias e mudanças internas para a empresa, visando efetivar o desenvolvimento sustentável internamente.

\subsection{Delimitação}

A delimitação deste trabalho é a abordagem e a melhor compreensão dos conceitos de responsabilidade social ambiental e sustentabilidade apresentados no referencial teórico e sua aplicação na Empresa Vale, observando suas práticas, projetos e ações.

Sendo assim, a análise busca as práticas mais relevantes no que diz respeito a gestão sustentável, para entender como estas podem ser usadas para trazer impacto positivo, e como a Vale se enquadra nessas classificações. 


\subsection{Relevância}

Entende-se que, com o crescimento industrial, o impacto da ação do homem também cresce. Em vista disso, torna-se necessário que as empresas busquem minimizar a degradação do ambiente com medidas e práticas sustentáveis.

O presente estudo tem sua relevância quando demonstra os conceitos de sustentabilidade e sua importância, analisando a aplicação empresarial, podendo servir de referência para futuras empresas, empresas atuais, assim como para a própria Vale.

Sua contribuição social gira em torno da análise crítica que cada indivíduo deve ter para internalizar a veracidade das informações apresentadas no mercado no que diz respeito à sustentabilidade, e examinar como se pode verificar se a empresa é de fato Social e ambientalmente responsável, entendendo de fato o que traz impactos positivos e até que ponto eles são válidos, tendo em vista outras práticas da empresa.

Em suma, a análise pode servir de reflexão empresarial e pessoal, gerando discussão sobre os caminhos que a sustentabilidade e a gestão sustentável estão seguindo, e para onde devemos ir. 


\section{Referencial Teórico}

Neste tópico serão apresentados os referenciais teóricos utilizados como base para a análise.

Primeiro, é apresentado a Responsabilidade Socioambiental e a Ação Social privada, vendo a relação entre ambas e como a ação social privada tem que ser um complemento da RSE. Depois, fala-se sobre as ferramentas da Responsabilidade Socioambiental: Pacto Global, Balanço Social, Global Reporting Initiative e SA8000.

Por fim, entra-se no conceito de Triple Bottom Line e Greenwashing, que mais adiante é citado novamente ao se falar de Environmental, Social and Governance e sua aplicação nas empresas.

\subsection{Responsabilidade Socioambiental}

Dentro desse cenário de aumento da discussão a respeito da sustentabilidade à nível mundial, começa-se a discutir o papel das organizações nesse âmbito, e surge então a Responsabilidade Social Empresarial, o estudo sobre o que esta seria, quais as vantagens que pode trazer para uma empresa, e como implantar essa mudança nas empresas.

De acordo com o livro "Responsabilidade Social e Cidadania" (SESI 2008), na página 22, o autor Roberto Bartholo pontua:

"o conceito de responsabilidade social empresarial associa-se ao fato de que uma organização é responsável pelos impactos que suas práticas e ações gerenciais produzem, que não se referem somente ao âmbito da empresa em si, têm cunho interno

e externo. Seu exercício é a gestão dos negócios não restrita apenas ao resultado econômico da atividade produtiva, mas à contínua aprendizagem, inovação e recombinações institucionais, subsidiadas nas práticas de gestão, na vontade política interna, [...] na qualificação, capacitação e conhecimento das ferramentas e técnicas associadas."

Ou seja, entende- se que uma organização deve ter uma gestão ética e responsável, promovendo sua atividade principal da operação com preocupação não apenas no lucro, mas também nos impactos internos e externos, tendo uma 
gestão de qualidade, promovendo o desenvolvimento social local e com preocupação ambiental, pois cada um desses pontos se afeta diretamente, e estão dentro de um sistema interligado.

As empresas, como agentes de desenvolvimento, não devem ter sua estratégia baseada somente na dimensão econômica, mas também no social e no ambiental, ou seja, devem ter uma estratégia baseada no tripé da sustentabilidade, buscando uma atuação mais de longo prazo, considerando os impactos não mercadológicos das decisões tomadas e procurando melhorar a sociedade com responsabilidade e sustentabilidade (INSTITUTO ETHOS, 2017).

Outro aspecto importante é a confiança gerada no mercado, através da transparência pela qual se tomam as decisões internamente, isso irá criar reciprocidade dos funcionários, compradores e acionistas, gerando não apenas maior produtividade e motivação, mas também alinhamento de valores a longo prazo e um relacionamento duradouro, que consequentemente aumentará o lucro.

Caso uma empresa foque apenas em um dos pontos, ela não será considerada responsável social e ambientalmente.

Outra definição estabelecida pelo Instituto Ethos de Empresas e Responsabilidade Social é que a Responsabilidade Social Empresarial

\footnotetext{
"implica práticas de diálogo e engajamento da empresa com todos os públicos ligados a ela a partir de um relacionamento ético e transparente" e é uma "forma de gestão empresarial que é baseada na relação ética e transparente da empresa com todos os públicos com os quais se relaciona e pelo estabelecimento de metas organizacionais que impulsionem o desenvolvimento sustentável da sociedade, preservando recursos ambientais e culturais para as gerações futuras, respeitando a diversidade e promovendo a redução das desigualdades" (ETHOS, 2007 p. 3)

Dessa forma, o conceito e definição de responsabilidade social empresarial se associa a alguns aspectos que envolvem uma empresa social e ambientalmente responsável, uma relação de preocupação da empresa com todas as partes interessadas, interna e externamente, portanto, com todos os stakeholders, garantindo e realizando ações que prezam o bem-estar de todos, a atenção para como ela interfere com o ambiente e quais são seus impactos, a relação/diálogo ético e transparente, e a contribuição de seu processo com o desenvolvimento sustentável relacionado às atividades principais da empresa, sendo constantes e sempre presentes dentro da organização.
} 
No livro Comportamento Organizacional Chiavenato explica que a responsabilidade social é um "grau de obrigações que uma organização assume por meio de ações que protejam e melhorem o bem-estar da sociedade à medida que procura atingir seus próprios interesses" (p.39).

Para Chiavenato, a responsabilidade social empresarial e a ética estão completamente ligadas, pois é o conjunto de valores e princípios da organização que vai guiar a maneira como ela se posiciona na sociedade e conseguirá catalisar as ações socialmente responsáveis.

Entende-se, então, que a busca pela lucratividade da empresa deve estar alinhada com a responsabilidade legal e com a preocupação com o ambiente como um todo, preocupando-se com o impacto no ambiente no qual ela está inserida, o que gerará um aumento da produtividade pois os funcionários estarão com um bem-estar desenvolvido, melhoria da saúde organizacional, pela imagem pública positiva, que impacta todos os parceiros externos e a minimização da regulamentação, pois entende-se que as empresas são mais confiáveis, o que diminuirá a pressão por legislação.

O autor Robert Freeman desenvolveu em 1963 a "Teoria dos Stakeholders". Essa teoria foi importante pois quebrou a visão tradicional da época de que a empresa deveria olhar apenas para os seus "Shareholders", que seriam os acionistas e proprietários da organização, estendendo a visão para a preocupação com todos aqueles impactados pela empresa. Segundo a teoria, a empresa precisa oferecer benefícios a todos os interessados para conseguir ser de fato uma empresa de sucesso, sendo essa a representação de uma empresa socialmente responsável.

É essencial que uma empresa se volte para a gestão dos diferentes stakeholders, que podem estar focados na parte monetária, sendo estes os acionistas ou provedores de capital para as firmas, como bancos, agentes financeiros e fundos de investimento, como podem também estar focados no produto em si, como os clientes, fornecedores e comunidades locais, ou na organização em si, incluindo toda a parte interna, como os funcionários, administração ou até mesmo um possível sindicato.

A gestão desses interesses é um grande desafio para qualquer organização. De acordo com Borges, é importante ter como base alguns fatores para 
administrar isso; por mais que não haja um padrão de modelo ideal, pois cada empresa irá necessitar de suas diferenciações conforme a situação na qual se enquadra, há algumas bases estabelecidas no livro (BORGES, 2001, P.83):

a- uma visão integrada e sistêmica - sempre se preocupar com o processo como um todo e com todas as partes da empresa e em como elas se interligam, nunca olhar isoladamente.

b- a melhoria contínua

c- uma perspectiva de atuação de longo prazo e sustentabilidade na operação dos negócios, abrindo-se mão de resultados de curto prazo, à medida que esses interfiram

na relação com os stakeholders - ou seja, é essencial para esse modelo de gestão, priorizar medidas que seguem com as ideias da responsabilidade social empresarial acima de lucro ou respostas empresariais mais rápidas, que saiam desses padrões.

$d$ - comunicação aberta e transparente com as partes interessadas, implicando adotar transparência, honestidade, integridade e padrões de conduta éticos - essenciais para os valores da empresa nesse modelo. uma visão integrada e sistêmica, o foco em melhoria contínua, uma perspectiva de atuação à longo prazo e a comunicação aberta e transparente com as partes interessadas. (BORGES, 2001, P.83):

Ou seja, é importante aqui a visão de que a responsabilidade social empresarial é um processo contínuo. Sempre revisando seus objetivos e metas, pois o ambiente está sempre em constante mudança, assim como os interesses da organização e o sistema no qual está inserido. 


\subsection{Ação Social Privada}

A Ação Social Privada é definida pelo Instituto de Pesquisas Econômicas Aplicadas (IPEA), durante a "Pesquisa Ação Social das Empresas" como:

"qualquer atividade que as empresas realizam para atender as comunidades em áreas como assistência social, alimentação, saúde, educação e desenvolvimento comunitário, compreendendo desde pequenas doações eventuais a pessoas ou instituições até grandes projetos mais estruturados, podendo, inclusive, estender-se aos empregados das empresas e seus familiares",

SESI, página 58

Dito isso, a ação social privada não promove uma transformação social contínua, e também não é relacionada ao "core business", ou seja, às atividades principais da organização e sim centra-se em problemas voluntários isolados e pontuais, que não se envolvem nas operações da empresa, não é relacionado às suas obrigações e valores empresariais, sendo um reflexo da boa vontade do alto escalão da empresa.

Além disso, geralmente tem impacto em curto prazo nessas situações de investimento externo, e pode relacionar-se com os mais variados temas.

Definido pela IDIS, Instituto de Desenvolvimento do Investimento Social, a ação social privada é a "doação de forma voluntária, por parte da empresa, de recursos financeiros, humanos, técnicos, gerenciais ou em espécie voltada para $o$ interesse público".

Sendo assim, observa-se que a Ação Social pode vir a ser um diferencial competitivo no mercado, mas também demanda planejamento operacional e financeiro e uma preparação por parte da empresa.

No livro Responsabilidade Social e Governança, o autor Cláudio Pinheiro Machado Filho apresenta a Pirâmide de Caroll, conforme a Figura 1. 
Figura 1 - Pirâmide de Carroll

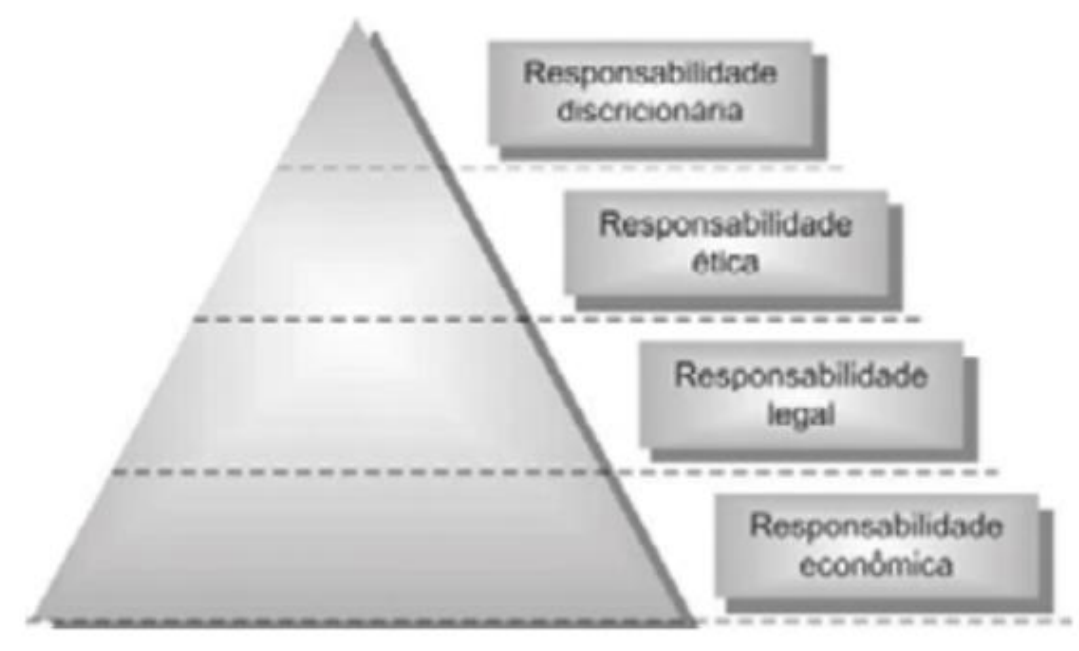

Fonte: Machado Filho (2006, p.25)

A primeira dimensão, sendo esta a base da pirâmide, a econômica, representa o sucesso da empresa em relação às suas atividades, produção e lucro, pensando sempre em maximizar o lucro para donos e acionistas acima de tudo. É a responsabilidade focada nos shareholdes, se opondo ao conceito de Freeman da Teoria dos stakeholdes citado anteriormente.

Empresas que olham apenas para a responsabilidade econômica tendem a tomar decisões e medidas visando o aumento do valor da empresa, e um maior retorno financeiro, independente dos impactos que isso pode ocasionar no ambiente e nas pessoas ao seu redor.

Além disso, a responsabilidade legal se baseia em agir de acordo com as políticas e leis existentes, engloba as obrigações legais e se encaixa no cumprimento de normas e valores sustentáveis. O segundo andar da pirâmide aponta para o cumprimento desse cenário legal buscando os interesses econômicos da empresa, que se encontram no primeiro andar.

A terceira dimensão, a responsabilidade ética, engloba agir com o comportamento adequado, seja dentro da empresa, com os interessados de fora, com seus fornecedores, acionistas ou até mesmo concorrentes, sendo regida pelo conceito de Responsabilidade Social Empresarial, que une as três responsabilidades já citadas acima. 
A última dimensão, a discricionária, se relaciona a não somente realizar o necessário para manter a harmonia com os interessados ao redor, e cumprir com a lei que envolve a atividade principal da empresa, mas vai além disso, realizando ações de cunho voluntário, desligados da operação organizacional, criando um diferencial enorme para a empresa, além de estar agindo de acordo com o futuro ambiental e com a preocupação global. Basicamente, propõe usar a força da empresa, não apenas econômica, mas seus recursos humanos e seu alcance no mercado para propor ações filantrópicas.

Enquanto a Responsabilidade Socioambiental envolve as três dimensões anteriores, legal, ética e econômica, a ação social privada é localizada no último andar da pirâmide, mas é importante ressaltar que ela deve ser realizada paralelamente às outras dimensões, e não isoladamente.

A responsabilidade discricionária, isoladamente dentro de uma empresa, por mais que possa trazer impacto positivo em algum âmbito, não irá anular os impactos negativos que a empresa possa vir a gerar por não cumprir a responsabilidade ética, por exemplo.

Então, é de extrema importância que a gestão da empresa foque, inicialmente em atuar internamente com as primeiras três dimensões, e, uma vez que estas sejam pilares para a organização, pense em ações filantrópicas para desenvolver, usando seus recursos e lucros para trazer algo de positivo ao planeta.

É importante, então, quando visualizamos uma ação social privada, entender de fato as intenções da empresa, investigando se ela segue os valores da RSE, ou apenas usa isso como um marketing positivo e apelativo, entrando no que se denomina GreenWashing.

Utting (2000, p.vi) afirma que devemos analisar diversos fatores em uma ação sustentável de uma empresa, mostrando que "estes fatores incluem as chamadas oportunidades do "ganha-ganha", a possibilidade de alavancar vantagens competitivas, a "gestão da imagem".

Ou seja, observamos a preocupação do benefício que as ações estão gerando. 
Entende-se então, que a Responsabilidade Socioambiental é um trabalho constante da empresa, um posicionamento e uma motivação que a acompanham em todas as suas ações, internas e externas.

Já a ação social privada, se liga apenas à um evento isolado, e deve ser observada junto a outros valores e atitudes da empresa, para envolver de fato o contexto como um todo, considerando se aquilo realmente representa a organização e o que ela incentiva no meio ambiente.

Philip Kotler (2011b) apresentou o conceito de "marketing holístico", mostrando que responsabilidade é você conseguir vincular suas ações com sua comunicação.

Michael Porter, em entrevista a HSMManagement, faz uma reflexão importante sobre as empresas que se dizem "verdes": "falar em fazer o bem e se preocupar com o futuro do planeta é um belo discurso, mas o fato é que a palavra sustentabilidade é muito vaga para as empresas com fins lucrativos" (PORTER, 2011, p.43). O exemplo disso na prática são diversas empresas com problemas nos órgãos como CONAR por propagandas ecológicas que não conseguem provar na prática.

Para visualizarmos um pouco mais o panorama da ação social no Brasil, ou seja, as atividades que as empresas realizam voluntariamente para trazer impacto positivo no ambiente e nas comunidades, o Instituto de Pesquisa Econômica Aplicada (IPEA) fez um estudo sobre Ação Social das Empresas, com cerca de 4 mil empresas brasileiras, buscando entender o comportamento das empresas que realizam ação social, suas motivações, dificuldades, como fazem, o quanto investem e outros fatores, entre o período de 1998 e 1999, e 2003.

A pesquisa contou com duas edições. A primeira foi realizada em 2002 e mostrou que grande parte das empresas privadas no Brasil investem, nem que o mínimo, em ação social, totalizando 59\%. Os resultados da 2a edição indicam historicamente esse comportamento. Realizada em 2006, mostraram que não houve apenas um crescimento do número de empresas que investiram em Ação Social, mas também um aumento do volume com que cada empresa realizava esses projetos. 
A pesquisa verificou que durante esse intervalo de tempo, a participação das empresas na área social aumentou de 59\% para 69\%, passando de 456 mil empresas, para 600 mil empresas brasileiras.

Entende-se, com essa pesquisa, que a preocupação organizacional de se envolver voluntariamente nessas questões está em uma curva crescente. Isso se dá por conta da mudança da mentalidade no mercado, que passou a olhar para questões sociais e ambientais como não apenas uma vantagem competitiva das empresas envolvidas, mas como uma obrigação das organizações.

Ao lado desse aumento, também irá aumentar a preocupação e responsabilidade dos stakeholders de avaliar mais criticamente as ações, e existem diversos conceitos que podem ajudar nisso, como as ferramentas da responsabilidade socioambiental, e as políticas ESG, as quais falaremos mais abaixo.

\subsection{Ferramentas da Responsabilidade Social Ambiental}

\subsubsection{Pacto Global}

A primeira ferramenta da Responsabilidade Social Empresarial a ser analisada é o Pacto Global: um conjunto de princípios aceitos por diversos países e organizações que estabelece o comprometimento das empresas com dez princípios universais, envolvendo os temas como direitos humanos, condições de trabalho, meio ambiente e combate à corrupção.

A proposta principal é fazer com que o mundo dos negócios contribua para formar uma economia global mais inclusiva e sustentável, incorporando os valores da responsabilidade social e contribuindo para o fortalecimento de outros atores sociais, buscando um mundo de negócios mais responsável socialmente, promovendo a inclusão e igualdade social.

As organizações aderem o Pacto preenchendo um formulário e assinando uma carta de compromisso e ele serve de base de como a empresa deve agir em relação aos diversos stakeholders e ao comportamento ético da organização relacionada aos temas abordados. A empresa sócia deve estar dentro dos 
acordos promovendo ações que se liguem aos princípios, e a empresa tem o compromisso prático de concretizá-las.

Fazem parte do Pacto Global dez princípios divididos em quatro temas, e através destes as empresas devem inclui-los internamente

\subsubsection{Direitos Humanos}

1. As empresas devem apoiar e respeitar a proteção de direitos humanos reconhecidos internacionalmente; e

2. Assegurar-se de sua não participação em violações destes direitos.

\subsubsection{Trabalho}

3. As empresas devem apoiar a liberdade de associação e o reconhecimento efetivo do direito à negociação coletiva;

4. A eliminação de todas as formas de trabalho forçado ou compulsório;

5. A abolição efetiva do trabalho infantil; e

6. Eliminar a discriminação no emprego.

\subsubsection{Meio Ambiente}

7. As empresas devem apoiar uma abordagem preventiva aos desafios ambientais;

8. Desenvolver iniciativas para promover maior responsabilidade ambiental; e

9. Incentivar o desenvolvimento e difusão de tecnologias ambientalmente amigáveis.

\subsubsection{Contra a Corrupção}

10. As empresas devem combater a corrupção em todas as suas formas, inclusive extorsão e propina. 
Essa ferramenta tem como alguns dos seus objetivos: facilitar a comunicação entre grupos societários divergentes e promover as melhores práticas e sua devida manutenção, promover o compartilhamento de um modelo único de cooperação entre empresas, uma união para uma economia mais sustentável e promover a inclusão social.

Um dos benefícios dessa ferramenta é que ela incentiva a empresa para incluir na sua lógica de funcionamento esses dez princípios que envolvem temas de significativa importância para estabelecer um ambiente de trabalho agradável, ético e sustentável, conseguindo ampliar a competitividade dos negócios em um mundo em acelerada transformação. Além de ser um sistema que tanto grandes e pequenas empresas podem aderir.

Apesar disso, uma desvantagem dessa ferramenta é que ela facilita que muitas empresas multinacionais vinculem seu nome à ONU sem atuações concretas que as justifiquem como socialmente responsáveis, já que não possuem auditores que garantem que os societários estão contribuindo para seus objetivos.

\subsubsection{Balanço Social}

A segunda ferramenta analisada é o Balanço Social. Trata-se de uma publicação anual pela empresa, apresentando informações sobre os custos da empresa com o valor investido no que diz respeito à seus projetos sociais e investimentos em Ação Social Privada e em sua Responsabilidade Social Empresarial.

Assim, segundo Tinoco (2002), "a sociedade inteira é o público alvo das informações contidas no Balanço Social', encontrada na página 146 do livro SESI (2008), isso inclui desde os grupos que prestam serviços a empresa (empregados), aqueles que usam/compram produtos seu (clientes), os acionistas potenciais e controladores, o governo, as autoridades monetárias, gestores, fornecedores, enfim, todos aqueles que fazem parte do ambiente interno e externo da empresa, assim como a sociedade como um todo, mesmo não estando envolvida na empresa, cada um possuindo interesses específicos.

O principal objetivo do instrumento é tornar pública a Responsabilidade Social Empresarial e ser um instrumento estratégico para avaliar e multiplicar o exercício 
da responsabilidade social corporativa, além de servir como um controle para própria empresa sobre os custos de investimentos em relação ao lucro empresarial, e uma própria forma de auto reflexão do que a organização poderia estar fazendo. Também é possível fazer comparações com a melhoria e evolução da empresa ao longo dos anos, e comparar com outras do setor e seus respectivos investimentos.

\subsubsection{Global Reporting Initiative}

A terceira ferramenta analisada é O Global Reporting Initiative (GRI), criado em 1997, a qual define um padrão internacional para a realização do relatório anual de sustentabilidade. Uma iniciativa que nasceu de uma organização não governamental, da parceria entre a Ceres (Coalition for Environmentally Responsible Economies) e o Programa Ambiental das Nações Unidas, com o objetivo de desenvolver e debater globalmente um meio de empresas aderirem à sustentabilidade corporativa, e visando difundir para as empresas como ser mais transparentes, além de ser uma forma de reconhecimento delas mesmas do impactos no ambiente.

Nascimento (2012) aponta que o GRI busca orientar as organizações que estejam elaborando relatórios sustentáveis e ajuda na articulação de suas contribuições em direção ao desenvolvimento sustentável.

Segundo o site do GRI, ele pode ser definido como "uma iniciativa de uma organização não governamental internacional, cuja missão é desenvolver e disseminar globalmente diretrizes aplicáveis para o desenvolvimento de relatórios de sustentabilidade utilizados voluntariamente por empresas que relatam as dimensões econômica, ambiental e social de suas atividades, produtos e serviços".

Essa ferramenta permite avaliar a consistência entre a política de sustentabilidade corporativa e sua efetiva realização. Ela se baseia em princípios que estabelecem condutas associadas a critérios de transparência e prestação de contas, bem como na sua organização a partir das dimensões econômica, ambiental e social da sustentabilidade. 
Na esfera econômica pode-se citar a criação de empregos, salários e benefícios, produtividade do trabalho, despesas em pesquisa e desenvolvimento, investimentos em treinamento e outras formas de capital humano; na ambiental o estudo do impacto dos processos produtos e serviços no ar, na água, na terra, na biodiversidade e na saúde humana e no meio ambiente; e na social a valorização dos trabalhadores a partir de fatores como o seu salário e o ambiente de trabalho, saúde e segurança, retenção de funcionários, direito dos trabalhadores, direitos humanos e condições de trabalho. (SIMÕES, 2008)

Ainda de acordo com Simões et al. (2008), é importante das destaque ao apoio de empresas e organizações não governamentais ao redor do mundo, para a realização da GRI, contando com a participação ativa de representantes da área de negócios, contabilidade, investimentos, meio ambiente, direitos humanos, pesquisas e organizações trabalhistas.

Como visto, é essencial que as empresas tenham o controle de suas ações, pois caso não tenham atingido a expectativa dentro do prazo estabelecido nos relatórios, elas deverão dar explicações sobre o problema nos planos de ação, e o porquê de não terem conseguido atingir o que pretendiam.

Essa necessidade de se justificar e mostrar o que fora feito de um relatório para outro para chegar ao que pretendiam faz com que as empresas tenham um maior comprometimento no processo.

São 11 princípios nos quais o GRI se baseia: transparência, inclusividade, auditabilidade, completude, relevância, contexto de sustentabilidade, exatidão, neutralidade, comparabilidade, clareza e conveniência. Possui como objetivo desenvolver diretrizes de relato (Sustainability Reporting Guidelines) que possam ser utilizadas e comparadas por organizações em todo o mundo e definir e melhorar continuamente as diretrizes de relatórios refletindo as três dimensões de sustentabilidade: econômica, ambiental e social.

As Normas GRI representam as melhores práticas globais para o relato público de diferentes impactos econômicos, ambientais e sociais. O relato de sustentabilidade com base nas Normas fornece informações sobre as contribuições positivas ou negativas de uma organização para o desenvolvimento sustentável (GLOBAL REPORTING INITIATIVE, 2020) 
A sua importância para as empresas que o realizarem gira em torno da análise completa sobre esses fatores, ajudando a empresa a ilustrar e entender suas ações de maneira extensa e profunda, e irá ajudar a guiar ações de implementação de diversas estratégias para a melhoria interna.

Além disso, o GRI complementa o Pacto Global tentando transformar seus princípios em algo mensurável e aplicável para as empresas que o adotam, através de seus relatórios, permitindo que as partes externas possam acompanhar as empresas (SIMOES et al., 2008).

O fato de ser padronizado também é extremamente benéfico para a comparação entre as empresas no que diz respeito à questão socioambiental, o que ajuda na avaliação por parte dos stakeholders, isso também facilita a sua execução, assim como o Balanço Social.

\subsubsection{SA8000}

A SA8000, nascida da necessidade de criar boas condições nas relações trabalhistas: regra mínima comum dessas condições, busca evitar trabalho escravo e exploração infantil e diversas questões sobre o assunto; é um conjunto de normas e especificações aceitas em nível internacional, que prevê certificação para as empresas, sendo passíveis de auditoria. O foco dessa ferramenta é a responsabilidade social interna da empresa com seus funcionários, não levando em conta questões ambientais ou o relacionamento com a sociedade, ou o que diz respeito à suas operações, apenas suas relações de trabalho dentro da organização.

A Norma SA8000 é a principal norma de certificação social para fábricas e organizações à escala global. Consiste numa estrutura abrangente que ajuda as organizações certificadas a demonstrar a sua dedicação ao tratamento justo dos trabalhadores nos vários setores e em qualquer país (SOCIAL ACCOUNTABILITY INTERNATIONAL (SAI), 2018).

"Trata-se de uma certificação desenvolvida com a participação de sindicatos, empresas e organizações não governamentais, que combina elementos-chave das convenções da Organização Internacional do Trabalho (OIT) com sistemas de gerenciamento das famílias ISO. Os códigos de conduta 
da SA 8000 são divididos em nove requisitos de responsabilidade social: (1) trabalho infantil, (2) trabalho forçado e compulsório, (3) saúde e segurança, (4) liberdade de associação e reivindicações coletivas, (5) discriminação, (6) práticas disciplinares, (7) horas de trabalho, (8) remuneração, (9) sistemas de gestão.", de acordo com o livro Responsabilidade Social e Cidadania" (SESI 2008), página 180.

Nesse sentido, a adoção da certificação da SA 8000 significa que a organização deve levar em consideração o impacto social de seu processo e atividades internamente, além de estar atenta as condições sob as quais os funcionários, parceiros e fornecedores estão trabalhando, conseguindo incentivar a organização a manter, desenvolver e aplicar práticas socialmente aceitáveis no seu local de trabalho.

A utilização dessa ferramenta se torna de significativa importância, pois ao obter a certificação, o público da empresa, sejam consumidores ou fornecedores, terá a certeza de que a organização leva em consideração o impacto social da atividade fim e desenvolve políticas para que seus funcionários trabalhem com qualidade de vida. Ademais, muitas empresas em nível internacional não aceitam fazer negócios com aquelas que não possuem essa certificação. Essa certificação pode ser aplicada para empresas de qualquer tamanho e de qualquer lugar do mundo, sendo uma certificação reconhecida pelo mundo inteiro.

Este certificado simboliza que a empresa tem preocupação com a natureza e está comprometida com a preservação do meio ambiente. (SIMÕES, 2008)

Assim, a certificação do sistema de responsabilidade social baseado na norma SA 8000 por uma entidade é uma forma de dar credibilidade ao trabalho da empresa e ainda ajudar no acesso a novos mercados e na construção da consciência de uma marca mais forte. 


\subsection{Triple Bottom Line}

Com a mudança na mentalidade do mercado, focando cada vez mais no que a empresa representa como um todo, em seu posicionamento, visão, missão e valores, muito mais do que de fato com o produto ou serviço que ela vende, o termo sustentabilidade se expande no mercado, assim como empresas social e ambientalmente responsáveis.

Assim surge o conceito de Triple Bottom Line, em português "Tripé da Sustentabilidade", de John Elkington (1997), que o desenvolve em seu livro Cannibals With Forks: The Triple Bottom Line of 21st Century Business. Ele abrange os aspectos econômicos, sociais e ambientais, e faz parte das empresas que são um diferencial no mercado, gerando valor para as organizações que seguem esse conceito, uma vez que a vantagem competitiva consegue alavancar a empresa e ajudar no crescimento do negócio e no seu posicionamento no mercado.

O autor Barbosa (2007), tentou explicar a origem do Triple Bottom Line através da transformação da mentalidade empresarial "Os componentes fundamentais para o desenvolvimento sustentável consistem em: crescimento econômico, proteção ao meio ambiente e igualdade social. Esses fundamentos aliados à mudança do paradigma das empresas, que tinham como único foco o lucro, passaram por uma concepção de desenvolvimento sustentável, dando origem ao TBL ou Triple Bottom Line da Sustentabilidade."

É um conceito muito presente nas empresas pois mostra como é possível para uma organização ser social e ambientalmente responsável e ainda assim gerar lucros, promovendo um equilíbrio entre os interesses financeiros e as políticas sociais e ambientais.

Para além disso, é defendido que para medir o sucesso de uma organização, não se deve olhar apenas para os resultados de receita, e sim para o impacto total de seus negócios.

As empresas, como agentes de desenvolvimento, não devem ter sua estratégia baseada somente na dimensão econômica, mas também no social e no ambiental, ou seja, devem ter uma estratégia baseada no tripé da sustentabilidade, buscando uma atuação mais de longo prazo, considerando impactos não mercadológicos das decisões tomadas e procurando melhorar a sociedade com responsabilidade e sustentabilidade (INSTITUTO ETHOS, 2017). 
O autor Michael Porter (1989) defendeu que a estratégia da empresa só será eficiente caso ela tenha objetivos tanto no meio econômico, quanto no social e no ambiental. Do contrário, são consideradas ambíguas e desfocadas.

A escolha do termo "tripé" já indica que temos que trabalhar os 3 pilares, que são estes: o social, o ambiental e o econômico, chamado também de 3 Ps (People, Planet e Profit).

Figura 2 - Tripé da Sustentabilidade

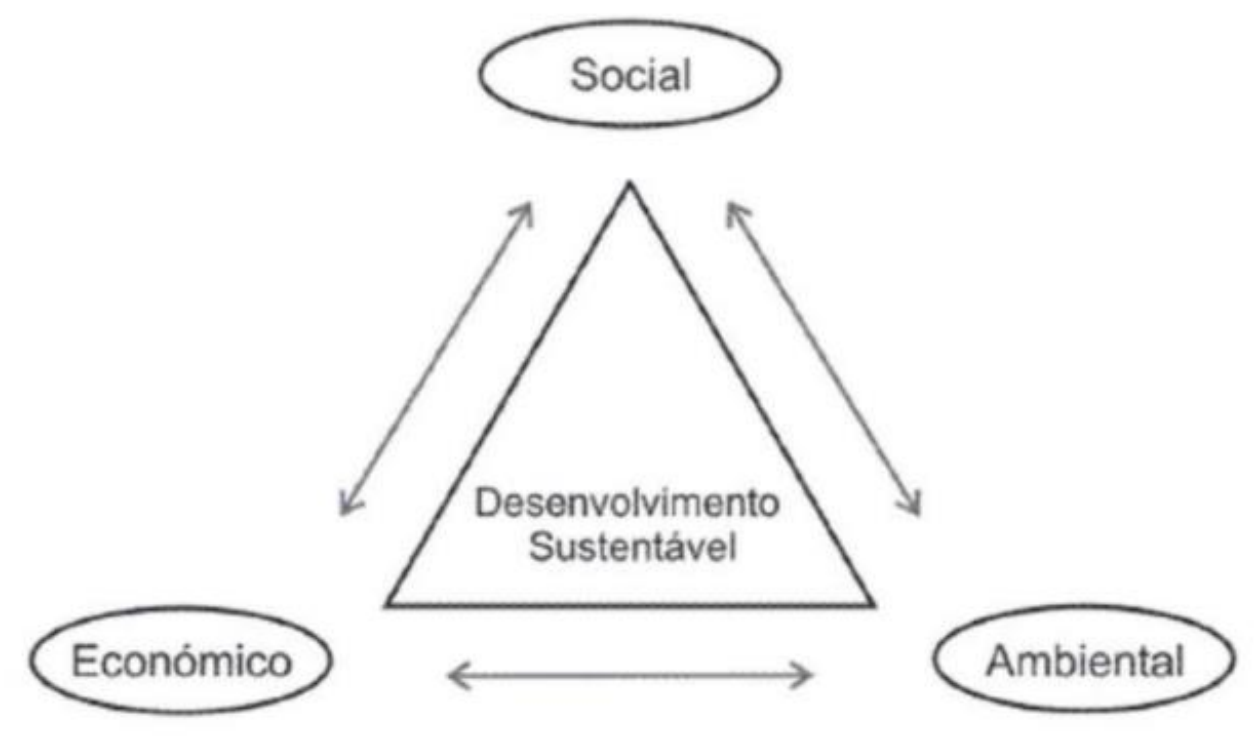

Fonte: Dias, 2011, p. 46

Quando pegamos o primeiro pilar, o de pessoas, fala-se de todos aqueles impactados pelas ações da empresa, sejam os funcionários, acionistas, consumidores ou até mesmo moradores de perto do local de atuação. A responsabilidade social envolve proporcionar uma boa qualidade de vida, e o bem estar de todos os stakeholders, diretos e indiretos da empresa.

Já ao falar do ambiente, é preciso entender quaisquer impactos que a atividade organizacional tenha no planeta terra, e trabalhar para reduzir as interações negativas, além de estar sempre em busca de desenvolver projetos e ações para ajudar o meio ambiente.

Para Bellen (2004), "sustentabilidade requer um padrão de vida dentro dos limites impostos pela natureza" (p. 73). 
O terceiro pilar aponta para a lucratividade da empresa. Uma organização que cuida das pessoas e do ambiente vai ser social e ambientalmente responsável, e agora ela precisa, dentro disso, conseguir acoplar valor ao seu produto ou serviço, e ter um negócio que gere lucro, dentro desses padrões estabelecidos pelos pilares acima.

Entende-se que a empresa pode ser considerada sustentável quando os 3 pilares estão sendo seguidos, e essas dimensões interagem de forma equilibrada.

\subsection{Greenwashing}

Para esse estudo, é importante investigar como o campo do marketing ambiental tem sido impactado pela prática do greenwashing, que pode ser traduzido por "lavagem verde", ou até mesmo como "maquiagem verde" ou "banho verde".

Esta se liga ao fato de que algumas empresas falseiam os dados obtidos, mascarando os reais impactos ambientais da sua atividade no meio ambiente, como também omitindo estas informações, produzindo uma distância enorme entre o seu discurso e as suas práticas. Algumas empresas fazem campanhas publicitárias dando ênfase ao meio ambiente, sendo que a campanha não é condizente com a realidade das atividades da empresa.

De acordo com Araújo (2007), em seu artigo "Ecoturismo ou Greenwashing?", uma empresa, organização não governamental (ONG) ou mesmo o próprio governo estão emitindo falsas impressões acerca de práticas ambientais quando as suas reais atividades apresentam-se contrárias aos interesses e bens ambientais.

Segundo o artigo "Greenwashing in environmental marketing strategy in the brazilian furniture market", de Caldas, Veiga-Neto, Guimarães, Castro, A. B. C. \& Pereira (2021), o marketing ambiental visa delinear estratégias que relacionem a imagem de uma empresa, seus produtos e suas marcas, à pauta do meio ambiente, tão central hoje em todo o mundo.

No entanto, pesquisas têm mostrado que tal prática pode trazer muitos prejuízos às empresas se as "mensagens verdes" forem utilizadas de um modo que haja uma distância entre o discurso e a prática operada pela corporação. 
Os autores realizaram pesquisas para verificar a prática de marketing ambiental em nosso país, podendo mostrar com os resultados como o greenwashing pode ser altamente prejudicial para uma empresa. Os consumidores, segundo os autores, já têm consciência das questões ambientais, mas rejeitam empresas que apresentem sinais de greenwashing.

Como efeito, a identificação de greenwashing em marcas e produtos produz nos consumidores uma perda de fidelidade e de satisfação, conforme demonstra a pesquisa apresentada no artigo "Greenwashing effect, attitudes, and beliefs in green consumption": "Quando greenwashing é identificado em um produto, este perde o aspecto de lealdade, satisfação e benefícios" (Braga Junior, Pagán Martínez, Miranda Correa, Cox Moura-Leite \& Dirceu da Silva, 2019).

Analisando o contexto atual, percebe-se que os recursos naturais foram sacrificados em prol do desenvolvimento, com o desmatamento e poluição e outros impactos da ação do homem, em âmbito ambiental e social, desde os primórdios da vida humana na Terra, é importante entender todo esse processo, e que cada passo em busca da modernização, foi um passo atrás no quesito de consciência ecológica e social.

O "despertar ecológico" vem desde o século passado, e está muito ligado à essa grande modernização global, ao lado da maior troca de informações sobre o assunto.

A pressão mundial também vem aumentando, tornando isso uma pauta de grande relevância, com maior percepção da sociedade sobre o que está acontecendo, como foi visto com o Relatório de Bruntdland e as comissões da ONU sobre desenvolvimento sustentável.

Como consequência, os consumidores começaram a ser mais exigentes com a qualidade ecológica dos seus serviços e produtos, considerando aspectos sociais, econômicos e ambientais. Assim, tem aumentado a procura e a conscientização sobre responsabilidade social e ecológica, e as empresas começam a perceber que, além da obrigação de ter essa visão, isso também representa uma vantagem no mercado, e, adotando essas mudanças, consegue ganhar mais espaço e público.

Surge então, o GreenWashing, como uma prática oportunista, que aproveita o movimento de conscientização ecológica e a busca por produtos e serviços que 
atendem as necessidades mais sustentáveis, criando produtos que contam essa história, para vender mais, sem de fato adotar essa posição na prática internamente na empresa ou não atende os padrões ecológicos estabelecidos.

Cada vez mais as pessoas estão mudando hábitos de consumo, e questionando-se sobre as marcas que consomem, buscando saber a origem do produto ou serviço, e os impactos da produção no ambiente, e o Greenwashing é justamente a linha tênue entre a Responsabilidade Socioambiental e a Ação Social Privada, pois uma Ação Social Privada, sem seguir, respeitar, e praticar a RSE é nada menos que praticar o greenwashing.

\subsection{ESG (Environmental, Social and Governance)}

ESG (Enviromental, Social and Governance) também é um termo que surgiu com o aumento da preocupação global a respeito dos impactos do homem no meio ambiente e os valores sociais e de governança da sociedade, em português, Ambiental, Social e Governança.

Segundo uma matéria do Jornal Negócios, publicada em 24 de agosto de 2021, o atual conceito ESG propõe a conjunção entre a sustentabilidade e estratégias da empresa visando o longo prazo ou sua capacidade de gerar valor no curto, médio e longo prazos. Além de ter como objetivo o lucro, a empresa deve se preocupar também com os impactos que suas atividades causam em todo o ecossistema - clientes, fornecedores, comunidades no entorno, meio ambiente e governo. Uma empresa que não se importa com a sustentabilidade não se mantém ao longo dos anos, ou seja, não é sustentável.

A grande repercussão que a nova onda da ESG vem tendo no mundo dos negócios tem inclusive mudado as estruturas e estratégias das empresas a fim de seguir as regras estipuladas por esta nova prática.

O termo ESG ganhou maior destaque com a divulgação dos 17 aspectos que devem ser implantados por todos os países até o ano 2030 com o objetivo de eliminar a pobreza, de proteger o meio ambiente e o clima e de garantir que as pessoas possam obter prosperidade. São como uma lista de tarefas a serem cumpridas pelos governos, sociedade civil, setor privado e todos os cidadãos. 
Por outro lado, a traumática pandemia do Covid-19 em 2020-21 também foi um fator que reforçou a necessidade urgente da implementação da ESG, conforme detalhado no Relatório "ESG nas instituições financeiras em 2021".

Em meio a isso, organizações vem se adaptando para reduzir esses impactos e, a longo prazo, se tornarem sustentáveis.

Temos três dimensões da ESG, sendo a primeira Ambiental que se refere justamente ao uso de recursos da companhia, se é de forma eficiente, sem desperdícios, sem poluição, prezando sempre pelo mínimo impacto negativo.

$\mathrm{Na}$ dimensão social se trata da relação empresarial com todos os colaboradores envolvidos, sejam internos ou externos. Nesse quesito entram o bem-estar dos funcionários, a CLT, visando sempre a diversidade e inclusão no ambiente de trabalho. Além disso os clientes e a sociedade também são levados em questão.

Essas duas dimensões conseguem se relacionar com a Pirâmide de Carroll, que diz respeito justamente à essas preocupações. Isso é reflexo da força que conceitos relacionados a Sustentabilidade estão ganhando no mercado, e como estudiosos e pesquisadores de todo o mundo vêm buscando entender melhor como é possível para as organizações adequarem seus negócios de forma a corroborar com o desenvolvimento sustentável ambiental e social.

Já a governança irá defender a importância de manter relacionamentos honestos e duradouros com seus colaboradores e isso inclui a honestidade e transparência frente aos acionistas, a prevenção de práticas ilegais e fraudes e exige um compromisso da empresa na mensuração e divulgação dos indicadores.

A transparência perante os envolvidos é de extrema importância para evitar o greenwashing, e por isso mesmo, o atual direcionamento do marketing ambiental deve, em suas premissas básicas, as recentes publicações sobre a ESG atestam os Reguladores têm cada vez estabelecido maiores exigências na observância de tais práticas por parte das empresas, conforme o artigo "Greenwashing effect, attitudes, and beliefs in green consumption": "Quando greenwashing é identificado em um produto, este perde o aspecto de lealdade, satisfação e benefícios" (Braga Junior, Pagán Martínez, Miranda Correa, Cox Moura-Leite \& Dirceu da Silva, 2019). 
A presença do Greenwashing fica ainda mais problemática devido ao incremento das exigências feitas pela ESG (Environmental, Social and Governance) nos últimos 5 anos. Sobre isso, uma interessante matéria publicada bem recentemente no Jornal Negócios, em 16 de agosto de 2021, "A onda ESG e as armadilhas das práticas green, social e rainbow washing", discute o envolvimento de certas empresas na prática de greenwashing.

A matéria mostra como diante da pressão do mercado como um todo para o atendimento às exigências de sustentabilidade, tem sido usual a presença em campanhas de marketing termos tais como verdes, sustentável, orgânico, vegano, entre outros. No entanto, muitas vezes este uso é indevido, ou seja, não corresponde à realidade.

Entende-se, com isso, que adotar a ESG não é apenas mais uma vantagem competitiva para o negócio, e sim virou condição para a sobrevivência deste no mercado, e de 2019 para 2021, 72\% das empresas aumentaram a quantidade de relatórios socioambientais, de acordo com um levantamento da Chief Executives for Corporate Purpose (CECP).

Mais uma vez conseguimos visualizar a importância de gerar valor para todos os stakeholders envolvidos, pois isso irá impactar diretamente na performance e sucesso da companhia, inclusive na motivação de seus funcionários e na receita anual ao longo do tempo.

Em meio a isso, em 2005 surgiu o Índice de Sustentabilidade Empresarial da Bolsa de Valores de São Paulo, a B3 (ISE B3), que reflete o retorno das ações das empresas da bolsa que seguem os termos da ESG, além de gerar um destaque para essas empresas, mostrando os diferentes níveis de qualidade e o compromisso com as dimensões ambientais, social e de governança. segundo a própria B3, "O ISE é uma ferramenta para análise comparativa da performance das empresas listadas na B3 sob o aspecto da sustentabilidade corporativa, baseada em eficiência econômica, equilíbrio ambiental, justiça social e governança corporativa". 


\section{Metodologia}

Nesse capítulo vamos apresentar como se deu a pesquisa, isto é a metodologia abordada no trabalho, tal como as etapas e como se deu o desenvolvimento deste.

Segundo Alyrio (2009, p. 100), "Método pode ser definido como: conjunto de regras, de normas, para busca de uma verdade, para detecção de erros na tentativa de alcançar uma finalidade desejada".

\subsection{Etapas do trabalho}

O trabalho se deu em 4 etapas: primeiro, a fundamentação do referencial teórico, através de estudos de livros, artigos, trabalhos e sites, sempre coletando dados secundários, para fazer o levantamento e concretização de conceitos já existentes e estudados na academia.

Segundo Tachizawa e Mendes (1999, p. 41), os dados secundários "são aqueles obtidos, por exemplo, de obras bibliográficas ou de relatórios de pesquisas anteriores sobre o tema".

Depois disso, houve a pesquisa da empresa Vale, se dada também através de relatórios, publicações, jornais, artigos, e principalmente das comunicações e site oficial da própria empresa, tendo suas fontes sempre de viés bibliográficos e documentais.

Em terceiro, fora feita a correlação entre o referencial e as práticas da empresa levantadas, para chegar ao objetivo do trabalho, de entender e analisar as práticas da empresa Vale, e como elas se enquadram na política sustentável,

Por último, como contribuição social, foi desenvolvido sugestões de gestão para os problemas levantados durante o estudo, e também tendo como base a conceituação teórica levantada no Referencial. 


\subsection{Método de pesquisa aplicado}

De acordo com Vergara (2007), os tipos de pesquisa podem ser definidos por dois critérios básicos: quanto aos fins e quanto aos meios.

Dito isso, entende-se que o presente trabalho, partiu do referencial teórico para contextualização do trabalho, com o intuito de aplicar e correlacionar ao estudo da empresa, com o objetivo de entender em detalhes as práticas empresariais, e conseguir, através disso, sugerir práticas de gestão, sempre com base na fundamentação teórica apresentada.

Com as definições de Gil e Vergara, relaciona-se a metodologia do trabalho à pesquisa descritiva explicativa.

Gil (2008, p.26), diz que "pode-se definir pesquisa como o processo formal e sistemático de desenvolvimento científico. $O$ objetivo fundamental da pesquisa é descobrir respostas para problemas mediante o emprego de procedimentos científicos", sendo assim os procedimentos científicos são os conceitos já existentes, usados para analisar os problemas de gestão da empresa Vale.

Segundo Vergara (1998, p.45), a pesquisa descritiva expõe características de determinada população ou de determinado fenômeno. Pode também estabelecer correlações entre variáveis e definir sua natureza. Não tem compromisso de explicar os fenômenos que descreve, embora sirva de base para tal explicação. Já a explicativa, tem como principal objetivo tornar algo inteligível, justificar Ihe os motivos. Visa, portanto, esclarecer quais fatores contribuem, de alguma forma; para a ocorrência de determinado fenômeno".

Concluindo, ambos as metodologias foram usadas para desenvolver esse trabalho, a descritiva no referencial teórico, com a apresentação dos conceitos contextualizando e guiando todo o trabalho, e a explicativa, justificando as análises da empresa e buscando entender o ambiente e práticas da empresa Vale. 


\section{Empresa Vale}

Nesse capítulo tratamos da empresa estudada no presente trabalho: a mineradora Vale, sendo inicialmente apresentado o histórico da empresa e como ela se encontra atualmente e um pouco de sua atuação, tanto das práticas positivas quanto alguns problemas de gestão relacionados.

Por último, é apresentado o uso das ferramentas de Responsabilidade Socioambiental mostrados no Referencial Teórico.

\subsection{A empresa}

A Vale é uma das maiores mineradoras do Brasil e do mundo, com sede no Rio de Janeiro. Foi fundada como uma empresa estatal em 1942, durante o governo de Getúlio Vargas, a Companhia Vale do Rio Doce e foi privatizada nos em 1997, em um leilão realizado na Bolsa de Valores do Rio de Janeiro, passando a ser controlada por grupos de investidores privados.

O novo Conselho de Administração da mineradora foi composto por quatro representantes da iniciativa privada (três da CSN e um do Opportunity), quatro dos fundos de pensão (três do Previ e um do Funcef) e um do clube de investimentos dos empregados.

Mais recentemente, em 2007, ela virou uma Corporation, o acordo de acionistas não foi renovado e hoje é uma empresa que não possui um controlador definido, sendo listada na Bolsa de Valores, com capital aberto. Encontra-se listada na bolsa de valores de São Paulo (B3), Nova York (NYSE) e Madrid (Latibex).

Assim, em 2007, ao ser efetivada como uma incorporação, o novo conglomerado empresarial CVRD Inco, a marca e o nome de fantasia da empresa passaram a ser apenas Vale S.A., nome pelo qual sempre foi conhecida nas bolsas de valores. Deixou de utilizar a sigla CVRD, mas manteve a razão social original. 
O minério de ferro ainda é o seu maior negócio, sendo considerada a maior produtora e exportadora do mundo de minérios de ferro, pelotas e níquel. A produção de alumínio encontra-se principalmente no estado do Pará, onde estão as maiores reservas de bauxita do Brasil.

Atualmente está presente em mais de 30 países e 5 continentes, investindo em projetos que envolvem a busca de reservas minerais para sua exploração. $A$ empresa também trabalha com logística, transporte dos minérios para ela mesma e também para terceiros. Além disso, a empresa também atua nos setores de energia e de siderurgia.

Em relação às operações da Vale, a maior delas é o minério de ferro de Carajás, no norte do Brasil, na Amazônia. O minério de Carajás tem sua qualidade reconhecida como sendo um dos melhores do mundo.

A empresa tem como missão "transformar recursos naturais em prosperidade e desenvolvimento sustentável', com o objetivo de ser referência entre as empresas de recursos naturais no que diz respeito à criação de valor de longo prazo: "ser a empresa de recursos naturais global número um em criação de valor de longo prazo com excelência, paixão pelas pessoas e pelo planeta".

Seus valores se ligam ao cuidado com a vida e aqueles que se relacionam com a empresa, agindo de forma ética e sustentável, além da valorização do meio ambiente, buscando "transformar recursos naturais em prosperidade e desenvolvimento sustentável'. Além destes, visa construir laços fortes e duradouros com os públicos com quem se relaciona, investir na mitigação dos efeitos das suas atividades, trabalhar com altos padrões éticos, ter uma gestão transparente e contribuir ativamente para avanços e impactos relacionados ao meio ambiente, biodiversidade e desenvolvimento sustentável. Para isso, a Vale se propõe a usar os recursos naturais globais para "a criação de valor de longo prazo com excelência, paixão pelas pessoas e pelo planeta"

A atual estrutura operacional da Vale conta com unidades operacionais interligadas a sistemas integrados de logística, compostos por ferrovias, terminais marítimos e portos. As coligadas, joint ventures ou de participação direta usam ativos nos segmentos de energia, de siderurgia e de bauxita em suas operações. Uma das suas principais ambições hoje é ser a líder mundial em mineração de baixo carbono. 
Apesar disso, a empresa enfrenta diversas questões judiciais, dentro e fora do Brasil, pois sua atuação já desencadeou muitos escândalos sociais e ambientais.

\subsection{Práticas Sustentáveis Positivas}

Nesse tópico serão analisadas diversas práticas realizadas pela Vale, as quais obtiveram impactos no âmbito social, ambiental e empresarial positivamente.

\subsubsection{Medidas de Redução de Consumo e Reutilização da Água}

A discussão a respeito do melhor uso da água está presente no cotidiano de empresas, indústrias, comércio, individual e doméstico, ao lado de uma necessidade de melhora no saneamento básico.

Em todo o mundo, discussões sobre economia e reutilização da água crescem ao lado da preocupação com a escassez de todas as reservas hídricas, tanto para uso pessoal como empresarial, e em todos os problemas que ela pode trazer para a humanidade.

Tendo em vista isso, a empresa Vale adotou diversas medidas e programas para redução no consumo e de reutilização da água. A seguir, são apresentados alguns exemplos de projetos da organização que tiveram e seguem tendo sucesso nesse âmbito para indicá-los como prática positiva realizada pela organização.

A relação dessa prática promove aos stakeholders da empresa uma imagem positiva de interação ambiental, o que pode interessar principalmente a seus acionistas, por aumentar sua publicidade positiva, além de seus funcionários, por saberem que a organização apresenta medidas que condizem com seus valores.

Essas medidas incluem o programa Meta Água, iniciado em 2018 para reduzir o uso de água doce em suas operações internas. 
Os programas contam com a criação de novas iniciativas, investimento e desenvolvimento, pesquisa e estudo de novas tecnologias para melhoria contínua e ampliação da rede de monitoramento e gestão dos recursos hídricos.

Vemos uma responsabilidade legal por parte da empresa, englobando as obrigações legais com as leis ambientais e se encaixando no cumprimento de normas e valores sustentáveis ao desenvolverem e programarem esses projetos, relacionados ao uso de água na atividade da empresa, relacionado à operação principal da empresa, trazendo benefício para sua própria produção e extração de minério.

A Vale busca sempre adotar uma política de transparência quando se trata de suas medidas positivas, para provar a eficiência de suas operações, e demonstrando seu valor para todos os interessados na empresa, mostrando suas práticas sustentáveis, e melhorando ainda mais a relação com os stakeholders envolvidos.

Um exemplo prático ocorreu no laboratório químico da Mina do Sossego, onde foi criada uma rede de captação automática a partir de reservatórios, a qual redireciona o líquido dos drenos, dos condicionadores e dos destiladores da operação local do Pará para o reservatório ao lado: Estação de Neutralização de Efluentes, onde a água passará por um novo processo de destilação no próprio laboratório químico, e estará pronta para ser reutilizada.

Ademais, a Vale adotou um método que não utiliza água no processamento do minério de ferro no Brasil, e investiu aproximadamente $R \$ 65$ bilhões para adotá-lo, tendo estimativa de mais instalações para que em 2024 represente um total de $70 \%$ de sua produção. Com isso, a economia gerada pelo projeto equivale à quantidade usada por 400 mil habitantes anualmente.

Através dos exemplos apresentados é possível ver que a empresa investe bastante tempo e recursos nessa prática, considerada como extremamente positiva que é a adoção de medidas de redução de consumo e reutilização da água dentro de seus processos internos de produção e extração de minérios. 


\subsubsection{Ações durante a pandemia}

A segunda prática positiva foram as reações da empresa num momento de pandemia mundial, como, por exemplo, a compra de testes de Covid-19 para serem doados ao governo brasileiro, classificada como uma ação humanitária realizada pela organização.

A Vale fez uso de sua rede de logística em solo asiático para encomendar da China 5 milhões de testes rápidos, que apresentam o resultado em apenas 15 minutos, para serem usados no sistema de saúde, ajudando no combate à propagação do vírus em todo o país.

Por conta de sua infraestrutura em solo chinês e parceria com o país, a facilidade de conseguir comprar e transportar a encomenda foi de extremo benefício nesse momento.

O Ministério da Saúde fez um agradecimento público às doações da empresa, o que reitera a imagem positiva para com seus stakeholders, afirmando que a inciativa possibilitou a realização do teste em diversos profissionais de saúde e outros que também estão na linha de frente do combate, o que tem como resultado a diminuição da contaminação em hospitais, por conseguirem identificar rapidamente as pessoas que estão infectadas, e isolálas.

A repercussão da ação teve um resultado muito positivo para a empresa, que aproveitou para desenvolver o "Vale Covid-19 Challenge" onde abre um espaço para atração de propostas de redução de impacto do vírus na sociedade, e seleciona projetos para enviar ajuda financeira, possibilitando com que aconteçam.

Os stakeholders se veem então, mais uma vez, incluídos na prática da empresa, como comentou Marcos Paranhos Calderon, funcionário da área de Inovação Aberta da Vale: "Estamos muito felizes com a massiva participação da sociedade. Para atingirmos esse resultado e materializar um novo modelo de inovação aberta foi essencial contar com a colaboração de parceiros externos e também dos empregados da Vale, de diversas áreas, que trabalham de maneira integrada e colaborativa" para uma matéria sobre o Desafio: "Desafio COVID-19: Vale recebe mais de 1450 propostas para reduzir os impactos do vírus na sociedade" disponível no site da própria empresa. 
Outro exemplo que se encaixa nessa prática positiva é a preocupação com os Estados onde a empresa atua, nos quais investiu $R \$ 1,5$ milhões no Hospital Municipal de Parauapebas, onde se localizam as reservas de Carajás, principal operação da empresa envolvendo o minério de ferro, para que eles esteja mais bem preparado para receber uma grande quantidade de pacientes infectados.

Diferentemente das medidas de redução de água, essas ações não estão ligadas à atividade essencial da empresa, tendo cunho voluntário e de doações pontuais, sendo consideradas filantropia. A Vale está indo além de suas responsabilidades para com seus stakeholders e com o meio ambiente e usando seus recursos para ações positivas sociais no âmbito salubre, auxiliando num período tão importante como o de crise.

\subsubsection{Conservação Ambiental}

A Vale é reconhecida por possuir medidas de conservação ambiental por todo território brasileiro. Ao todo já são $8,5 \mathrm{mil} \mathrm{km}^{2}$ de áreas protegidas pela mineradora, valor aproximadamente 5,6 vezes maior do que o total da área ocupada pelas unidades operacionais da empresa. Do total de áreas que a empresa ajuda a proteger, 4,5\% são próprias, constituídas por áreas de reserva legal, Reservas Particulares do Patrimônio Natural (RPPN) e propriedades destinadas a conservação.

Nesse sentido, a Vale vêm assumindo compromissos e responsabilidades com a recuperação de áreas no Brasil. A empresa adotou uma medidas de conservação ambiental que visa até o ano de 2030, ter realizado a recuperação de um bilhão de $\mathrm{m}^{2}$ de áreas degradadas.

A mineradora já iniciou o seu processo de conservação ambiental com diferentes projetos. Uma das principais áreas protegidas pela Vale é a sua Reserva Natural, localizada em Linhares, município do Espírito Santo. A Reserva Natural Vale (RNV) preserva uma área singular de Mata Atlântica praticamente intacta em Linhares, no Espírito Santo. São cerca de 23 mil hectares equivalente ao tamanho de 23 mil campos de futebol. 
Além disso, ela fica aberta ao público, sendo um espaço para a prática do turismo ecológico, pois está situada no Circuito do Verde e das Águas, umas das principais rotas turísticas do Espírito Santo. O local conta com ampla área verde para lazer, oferece caminhadas em trilhas, em ponte suspensa, torre para observação, oficinas ecológicas e um centro de visitantes com uma exposição permanente sobre a Mata Atlântica.

É válido ressaltar que os visitantes exploram apenas $1 \%$ de toda a reserva visando o não comprometimento do habitat dos animais. Além disso, a reserva não somente é uma área de conservação da diversidade biológica e uma área de opção de lazer, mas também um espaço para o desenvolvimento de pesquisas científicas de importante repercussão para a sociedade e essenciais para o conhecimento e manejo da floresta.

A RNV, portanto, é reconhecida como um grande refúgio de vida silvestre, pois desde o momento em que foi adquirida pela Vale, a reserva virou abrigo de mais de 3.000 espécies vegetais, uma fauna já identificada composta por 1.478 morfoespécies de insetos, 27 espécies de peixes, 56 espécies de anfíbios, 64 espécies de répteis, 400 espécies de aves e 102 espécies de mamíferos e possui mais de 241 projetos de pesquisas desenvolvidos. Dessa forma, possibilitado pelo seu sistema de proteção ecossistêmica, a Reserva apresenta um serviço de conservação da biodiversidade ameaçada de extinção na região.

Para conseguir manter esse serviço eficiente, a empresa empreende ações contínuas e preventivas contra caçadores, coleta de espécimes da fauna silvestre, extração ilegal de madeira, coleta de recursos botânicos e busca prevenir a ocorrência de incêndios, além de ações colaborativas de proteção das unidades de conservação públicas vizinhas.

Assim, o espaço da "Reserva Natural da Vale" consegue reunir importantes objetivos, como a conservação da biodiversidade e dos serviços ecossistêmicos, ser um espaço de produção de conhecimento, de restauração florestal e de educação ambiental, sendo todos esses pilares de significativa importância para a conservação do meio ambiente, ainda mais na sociedade atual.

Outro projeto de conservação ambiental instaurado pela Vale são os seus Parques Botânicos, também abertos gratuitamente para a visitação do público, 
criados e administrados pela própria empresa. São três Parques: o Parque Botânico de Vitória, o Parque Botânico de São Luís e o Parque Zoobotânico de Carajás, todos eles destinados a abrigar e preservar diversas espécies da fauna e da flora local de cada região, impedindo a devastação por atividades humanas.

O primeiro Parque faz parte do Cinturão Verde da Vale (projeto de revegetação do complexo de Tubarão, em Espírito Santo) e é uma unidade de conservação da Mata Atlântica, uma das mais importantes florestas do país. $O$ segundo Parque conserva 100 hectares de fauna e flora raras, e o terceiro Parque, localizado dentro da Floresta Nacional de Carajás, representa uma Unidade de Conservação Federal, e ocupauma área de 30 hectares preservados, o que permite a livre circulação de espécies de aves, cutias e macacos nas áreas de visitação e também conta com conta com zoológico, hospital veterinário, orquidário, herbário, sala de coleções, auditório, área de exposição e sala de educação ambiental.

Dessa forma, os parques são locais, abertos à visitação e abrigam centenas de espécies de árvores e são habitat de vários animais, e além de preservar a área, ainda fazem com que os visitantes tenham acesso a ações educativas voltadas para a preservação ambiental, como oficinas, eventos e trilhas ecológicas.

A Vale também possui uma riqueza natural preservada por 20 anos: a Reserva Particular do Patrimônio Natural (RPPN) Mata do Jambeiro. Essa é a maior área particular de preservação ambiental da Região Metropolitana de Belo Horizonte, em Minas Gerais, localizada na Serra do Curral, em Nova Lima. A Reserva encontra-se na transição de dois biomas considerados de importância mundial para a conservação da natureza: Mata Atlântica e Cerrado.

Essa unidade de preservação também é um habitat de diversas espécies da fauna e da flora. Além disso, contribui para o equilíbrio climático, preservação de cursos d'água e formação de corredores ecológicos que permitem a continuidade da biodiversidade da grande Belo Horizonte, e devido a essas características, recebeu certificação pela Unesco como de extremo valor conservacionista. Dessa maneira, o Jambeiro torna-se um dos exemplos efetivos de compromisso da Vale com a sustentabilidade, já que a empresa preserva uma área 3,5 maior do que a utilizada para realizar a sua atividade mineradora. 
Essa prática da mineradora desperta um interesse ainda maior para os stakeholders da empresa. Isso porque, com essas medidas e os seus resultados, a Vale está atuando de forma coerente com os seus princípios sustentáveis, e isso pode atrair um maior número de investidores e ganhar uma vantagem competitiva em relação aos seus concorrentes.

Além disso, a Vale com essas atitudes de preservação e conservação das áreas, está trazendo um maior conhecimento e educação ambiental pra o seu público e os seus clientes, já que possui espaços educativos abertos para visitação nessas áreas e também promove ações colaborativas de proteção das unidades de conservação das comunidades vizinhas, estabelecendo uma relação mais forte e positiva com os seus stakeholders.

Por meio desses projetos de conservação, a Vale está coerente com os seus principais princípios relacionados à sustentabilidade e possui uma atitude positiva e ética, respeitando a fauna e flora, o que é um bom reflexo para seus trabalhadores saberem que estão inseridos numa cultura que faz algum bem ambiental.

\subsection{Problemas de Gestão}

\subsubsection{Rompimento das barragens de Mariana e Brumadinho}

A primeira prática negativa da empresa Vale se relaciona a dois escândalos ligados ao rompimento de duas barragens da mineradora, localizadas em Minas Gerais, em 2015 e 2019, ambos consideradas crimes ambientais, na barragem Fundão.

O rompimento da barragem Fundão, no dia 5 de novembro de 2015, em Mariana, pertencente à empresa Samarco, controlada pela Vale, provocou uma enxurrada de lama, devastando o distrito de Bento Rodrigues. Foram atingidos 39 municípios, casas foram destruídas e diversas pessoas ficaram desabrigadas, além da ocorrência de 19 mortes, e diversos feridos, incluindo moradores da região e funcionários da própria mineradora. 
A lama no local também impediu o uso do espaço na atualidade e desenvolvimento futuro, sendo um impacto ambiental permanente das operações da empresa, e uma consequência direta delas. Os impactos ambientais causados por essa prática negativa estão principalmente relacionados aos componentes envolvidos nos rejeitos, que eram tóxicos (apesar das empresas envolvidas não assumirem), e capazes de devastar grandes ecossistemas pelo fato de o tornarem inférteis, levando à extinção do local do acidente e à destruição da vegetação da região, além das consequências para aqueles que foram contaminados.

O rastro de destruição avançou ao lado do Rio Gualauxo e do Rio do Carmo, afluentes do Rio Doce, esgotando os recursos hídricos da região, já que ele abastecia as cidades ao redor, soterrando nascentes e matando algas e peixes (impedindo o trabalho dos pescadores e o desenvolvimento da cadeia alimentar local). Ademais, a lama chegou também na foz do Rio Doce, no Oceano Atlântico, na altura que banha o Espírito Santo e abriga um importante recife de corais, o que provoca ainda mais consequências à vida aquática.

A destruição da cidade e o impedimento de acesso à água por esse desastre é um fator que afetou diretamente o bem-estar e a qualidade de vida dos moradores ao redor da área de atuação da empresa.

Em relação ao envolvimento da mineradora, a causa do rompimento se dá principalmente por falhas na construção. A mineradora construiu diversas barragens com um sistema de economia de custos, que se dá pelo uso de rejeitos escavados durante a mineração, na construção. Esses resíduos contém água, portanto, já é previamente sabida a necessidade de monitoramento constante. Já havia preocupações com a falta de segurança desse empreendimento, que foram negligenciadas pela empresa, mostrando a ciência a respeito da gravidade em que a situação se encontrava. Isso se deu, provavelmente, pelo fato dos custos de manutenção e reconstrução para um sistema mais seguro serem extremamente elevados.

Ademais, a fiscalização dessas estruturas é imprescindível e conhecida por qualquer empresa do setor, tendo em vista os inúmeros riscos e consequências que podem ser causados pelo rompimento, porém, o monitoramento constante dessas barragens requer uma tecnológica de alto custo. 
Existem também outros meios de exploração de minério, com um mínimo impacto ambiental, e soluções seguras que não armazenam lama, e substituiriam barragens em risco, porém, essas medidas também requerem grande investimento.

Tendo em vista que existem diversas soluções que a Vale poderia ter adotado para evitar o desastre de Mariana, porém não o fez, observa-se que os valores apresentados e defendidos pela empresa não estão presentes em suas ações operacionais, e que a preocupação com os stockholders é a maior prioridade, mantendo o curso de suas operações apesar dos riscos, visando o lucro contínuo e menor gasto com ações de reparação e monitoramento das barragens.

Também se alerta sobre a ausência de um plano emergencial de defesa e alarme com sistema de comunicação à cidade no caso do desastre, o qual já era um receio dos moradores da região, mostrando mais um descaso das empresas envolvidas com seus stakeholders.

Apesar da criação da Fundação Renova, responsável por dar auxílio ás vítimas, ainda há milhares de pessoas que não foram indenizadas pelos danos, sejam materiais, ligados à saúde física e mental, ao desemprego, à morte de familiares, a queda de renda ou outros.

A Vale, até hoje, não pagou nenhuma multa ambiental ao Instituto Brasileiro do Meio Ambiente e dos Recursos Naturais Renováveis (IBAMA), e ninguém foi responsabilizado pelo crime. Além disso, a lama tóxica ainda continua no local afetado, e o Rio Doce continua soterrado, mostrando que a empresa não está se responsabilizando pelo desastre ou pretende tomar medidas para a recuperação total do local e outras soluções.

Apesar disso, sua relação com os acionistas permaneceu boa uma vez que a empresa teve uma recuperação e crescimento muito rápidos, em relação ao seu Lucro, nos anos que seguiram o desastre, mostrando que as ações adotadas no decorrer da compensação não eram focadas naqueles afetados pelo rompimento e sim nos stockholders, se enquadrando na Pirâmide de Carroll como responsabilidade econômica, maximizando lucro para donos e acionistas acima de tudo. 
No dia 25 de janeiro de 2019, um novo desastre envolvendo a empresa aconteceu na cidade de Brumadinho, deixando 272 mortos, 11 desaparecidos e a cidade inteira abalada. Dessa vez, a Vale era a dona da barragem, e não apenas sua controladora.

Esse segundo desastre demonstra um descaso e negligência ainda maior da empresa com sua Responsabilidade Social Empresarial, pois mesmo depois da primeira tragédia, não buscou reparar seus erros evitando esse outro evento ou aumentar a manutenção e fiscalização de todas as suas barragens. Além de demonstrar a impunidade desse setor no Brasil e fragilidade da regulação dessa área.

O caso se repete na questão de que, novamente, não havia planos de alerta para os moradores da região. A Vale afirma que possuía um sistema de sirenes, mas que não tocaram por conta da "rapidez" do deslizamento, algo que deveria já ter sido prevista pelos especialistas responsáveis. A qualidade da água do Rio Paraopeba também foi afetada, a lama, mais uma vez, considerada tóxica por diversos especialistas e tendo o fato negado pela empresa, mostra que todos os erros de Mariana não serviram de ensinamento para a organização.

A empresa não realizou treinamentos com as cidades na área da barragem, e não revisou os procedimentos de segurança dos funcionários, colocando-os em risco diário em todas as suas barragens construídas do mesmo jeito de Mariana.

Somente após esse segundo desastre, foi anunciada a eliminação de outras dez barragens da mineradora que foram construídas do mesmo jeito e também possuíam os mesmos riscos.

Em ambos os casos, as avaliações de segurança prestadas pela própria Vale não emitiram qualquer tipo de preocupação com a possiblidade de rompimento das barragens, driblando possíveis custos de manutenção, pois afirmavam a estabilidade e segurança da barragem. Os documentos foram provados como irregulares somente após o rompimento e a avaliação tida como falsa. Mais um indício de que, se a inspeção tivesse sido feita de maneira correta, a organização poderia ter adotado estratégias de redução das consequências, ou até mesmo evitado o desastre. 
Além disso, engenheiros e empresas de consultoria contratados pela própria empresa afirmaram ter reportado os riscos relacionados à barragem, e também foram negligenciados.

Para complementar, a Vale tem um sistema muito desenvolvido de monitoramento de riscos, com um comitê de risco, incluindo relatórios constantes realizados por diversos técnicos do setor, além de uma gerência de riscos corporativos, o que torna inviável pensar que o cenário de insegurança de ambas as barragens tenha passado despercebidos pela gerência e mostra que eles tinham toda a estrutura para evitar ou minimizar os efeitos de ambos os desastres.

Por mais frouxas que sejam as leis ambientais nesse setor e toda a área de fiscalização e licenciamento, cabe à empresa Vale assumir responsabilidade por seus atos, sem precisar de leis ou auditores, e ser capaz de cumprir com os valores ambientais e sociais previstos por ela como organização.

Caso não tenha ficado claro com o primeiro desastre o descaso da Vale com seu papel de responsabilidade social e com seus stakeholders, não apenas pondo em risco seus funcionários, mas todos os moradores da região e também o meio ambiente, o fato de que nada foi feito para evitar que a situação se repetisse é ainda mais grave.

A escolha de fazer economias em recuperação, em manutenção e em compensação está de acordo com a política de maximização do lucro.

Uma interessante relação dos colaboradores foi perceber que, apesar da empresa ter tido sua maior queda nas ações no ano de Mariana, somente dois anos depois teve uma valorização de $83 \%$ e atingiu seu maior valor de mercado em 2018, com adoção de novas políticas de mercado e de dividendos e reestruturação societária. Isso mostra que, mesmo que os acionistas tenham se preocupado com a má conduta da Vale, eles continuaram investindo a partir do momento em que viram uma perspectiva de crescimento monetário. 


\subsubsection{Reassentamentos das comunidades em Tete}

A segunda prática negativa da Vale a ser analisada é a implantação de uma mina da Vale em Moçambique, na província de Tete, no centro do país.

O carvão mineral é extraído e exportado para a região norte do país, para o qual a Vale construiu linhas férreas para Nacala, e para o Porto da Beira, localizados no centro do país.

Para dar lugar ao projeto de extração de carvão da Vale, em 2009, cerca de 1.300 famílias foram retiradas de suas terras ocupadas há gerações para dar lugar ao projeto da empresa na província de Tete.

Essas comunidades moravam nesse local e se dedicavam à agricultura de subsistência. A companhia brasileira garantiu indenização e construiu dois reassentamentos: um fica perto da mina; e outro, em Cateme, uma vila distante quase à 40 quilômetros de onde as famílias viviam.

Ressalta-se que, ao deslocar as pessoas para um reassentamento, é necessário garantir condições de vida iguais ou superiores às anteriores do seu território de origem, ou seja, a falta do cumprimento disso, está de acordo com a falta da responsabilidade legal por parte da organização.

Apesar disso, a Vale não cumpriu com suas promessas: as terras distribuídas para as famílias são fortemente criticadas por serem impróprias para agricultura, contendo pedregulhos e outros empecilhos, e, como as comunidades obtinham como base a produção agrícola, elas sofreram significativamente com essa ação da Vale. Essa postura da Vale para com as famílias afetadas por ela mostram, mais uma vez, a postura da empresa de priorizar os seus interesses operacionais e lucrativos acima do bem-estar social daqueles afetados por suas operações.

Uma outra consequência dessa prática é, segundo o diretor-executivo da Associação de Apoio e Assistência Jurídica às Comunidades (AAAJC), Rui de Vasconcelos Caetano, em uma entrevista para o site de notícias RFI em "Mina da Vale em Moçambique é criticada há quase cinco anos": "o fato de que as pessoas 
que moram no entorno da mina também tenham sofrido os impactos da exploração de carvão".

O carvão mineral é transportado de forma aberta e acaba jogando resíduos e substâncias poluentes sobre as comunidades que vivem próximas à linha férrea, ingerindo essas substâncias.

Nesse sentido, também há a poluição do ar e dos rios, que são responsáveis por abastecer as famílias, e agora estão contaminados pelas ações da mineradora. O Instituto de Estudos Sociais e Econômicos Moçambicano (lese) constatou a presença de poluentes como dióxido de enxofre, óxidos de nitrogênio e monóxido de carbono na região, gases altamente tóxicos e que prejudicam, fortemente, a qualidade do ar inalado, podendo gerar até mortes.

Dessa forma, as famílias vivem com dificuldade de acesso à água, terra, energia, em solos impróprios para a agricultura, e não receberam, até o momento, as indenizações integrais a que têm direito. As casas de qualidade, construídas e prometidas pela própria Vale, já passaram por reformas ao menos três vezes devido às rachaduras, aos vazamentos e à erosão que abala a estrutura das casas.

Vários protestos já foram realizados pelas famílias reassentadas, alguns com o bloqueio das estradas que dão acesso à mina da Vale, denunciando as precárias condições de vida a que estão sujeitas desde o final de 2009. De acordo com João Salicuchepa Gimo, que é um dos moradores da região com a mulher e sete filhos no assentamento de Cateme, ele afirma: "Nos prometeram dois hectares de terra, só deram um, e uma terra ruim que não rende nada. Quando houve o primeiro contato com a população, o discurso foi de desenvolvimento, de muito emprego. Então, isso criou expectativa, e essa expectativa fez com que as comunidades, sem pensar, aceitassem todos aqueles tipos de condições. Hoje, estamos meio frustrados com a presença desse mega projeto, porque só nos traz sofrimento" em uma entrevista para o RFI disponibilizada na notícia "Mina da Vale em Moçambique é criticada há quase cinco anos."

Essa prática, implantada pela Vale, impacta negativamente os stakeholders da empresa, principalmente as comunidades locais, que estão sendo diretamente afetadas por essa ação da mineradora. Nesse sentido, a gestão de relacionamentos com essas comunidades locais e tradicionais ficam deterioradas, 
já que está sendo um relacionamento prejudicial para uma das partes, sem gerar benefícios mútuos.

\subsubsection{Práticas Desleais com trabalhadores durante o Coronavírus}

A terceira prática negativa a ser analisada é o fato da Vale ter mantido as suas operações em meio à pandemia do COVID-19.

A empresa Vale está colocando em risco, principalmente, a população do Pará e de Minas Gerais ao não paralisar suas atividades em meio à desafiadora crise do novo Coronavírus, uma vez que o trabalho envolve uma aglomeração de pessoas. Nesse sentido, a mineradora optou pela polêmica decisão de exigir que os seus milhares de funcionários continuem se encontrando e trabalhando durante o período que supostamente deveria ser de quarentena, contrariando todas as recomendações estabelecidas pela Organização Mundial da Saúde (OMS), e deixando que apenas parte dos funcionários de áreas administrativas tivesse a permissão para trabalhar de casa.

Destaca se ainda que a atividade mineradora não está presente na lista de atividades essenciais definida em decreto do governo federal, tornando-se uma opção exclusiva da Vale de manter as suas operações, mesmo sabendo que está colocando os seus funcionários em risco mortal.

Uma das maiores complicações é que os trabalhadores que atuam nas minas da Vale estão circulando com frequência por todo o Brasil. Dessa forma, por exemplo, no Complexo de Carajás, onde funciona a maior exploração de minério de ferro do mundo, encravada na floresta amazônica, há um significativo fluxo de pessoas de diversos estados, consequentemente, contribuindo para um maior contato entre as pessoas, podendo causar um maior contágio do vírus.

Não só no Complexo de Carajás que está ocorrendo aglomerações, mas também no Corredor Norte da Vale no Pará que inclui as operações S11D, Carajás, Salobo 3 e Sossego, em Marabá, Parauapebas e Canaã. Por conseguinte, com as atividades ocorrendo normalmente, vinte e quatro horas por dia, os ônibus continuam circulando pelas estradas constantemente, transportando trabalhadores entre os alojamentos lotados. 
Um dos operadores de equipamentos da Vale na Mina de Carajás, Evaldo Fidelis, manifestou a sua insatisfação com a falta de preocupação e responsabilidade da empresa, dizendo em uma entrevista para o The Intercept Brasil disponível na notícia "Coronavírus: mesmo com empregados contaminados, Vale mantém operação e aglomerações em minas": "O Complexo Carajás é muito dinâmico. Você tem pessoas de vários estados do Brasil e de vários lugares do mundo trabalhando e circulando. A maioria dos funcionários é de Parauapebas, inclusive das comunidades rurais que não têm nenhum suporte. Se o vírus chegar, vai ser a tragédia".

Os funcionários e representantes sindicais da operação mineira da empresa já pediram a paralisação total das atividades, sem o corte de salários e com garantia de emprego, porém até o momento não foram ouvidos.

Apesar da Vale ter se pronunciado e dito que adotou medidas para solucionar o problema, como: orientações à trabalhadores dos grupos de risco a ficar em casa, medição da temperatura corporal, aplicação do questionário de saúde na chegada dos operários ao trabalho, recomendações para qualquer um com sintomas de gripe fique 14 dias em casa, além de ter afirmado o aumento da frota de ônibus para reduzir a lotação, medidas para aumentar o distanciamento social nos restaurantes e alterado horários de entrada e saída dos trabalhadores para evitar aglomerações, a mesma não tem mostrado esses compromissos na prática, e as suas medidas não tem feito nenhum efeito.

Por exemplo, parte das medidas passou a valer somente depois que já havia cinco dias que um funcionário da empresa em Minas Gerais tinha sido diagnosticado com o Covid-19. No Pará, a triagem não é feita em todos os funcionários e como a maioria dos trabalhadores não tem menos de 60, ou seja, não se encontra no grupo de risco, o funcionamento da empresa segue normal, e aglomerações na entrada e saída continuam a ocorrer.

Observa-se, portanto que a Vale não está cumprindo o seu papel social, se distanciando dos próprios valores da empresa citados no site, como "a vida em primeiro lugar", "cuidar do nosso planeta" e "agir de forma correta", e não está interessada em buscar uma solução para proteger a saúde de todos os membros da organização. 
Além disso, em países como Canadá e Malásia, a empresa adotou uma postura diferente em comparação ao Brasil: a mineradora, nesses países, diminuiu ou paralisou suas operações. Sendo questionada por essa postura incoerente, a empresa alega que "está em conformidade com os protocolos de saúde e segurança estabelecidos pelas autoridades e agências de cada um dos países em que opera e está monitorando o desenvolvimento da situação" também disponível na notícia "Coronavírus: mesmo com empregados contaminados, Vale mantém operação e aglomerações em minas" do Intercept Brasil. Porém é visível que isso não está sendo seguido de forma correta e que essa prática não está sendo de responsabilidade social empresarial.

Nesse sentido, o impacto dessa prática afeta diferentes stakeholders da empresa, principalmente os funcionários e investidores. Os primeiros, pois com essa atitude da Vale, ela demonstra não valorizar suficientemente os seus colaboradores já que não está fornecendo os melhores cuidados, e isso pode causar uma desmotivação e perda de eficiência futuramente, além do risco que os está expondo de contrair o vírus. Em relação aos investidores, esses são afetados, pois, como os princípios da mineradora não estão sendo postos na prática, com essa atitude desleal e contrária às recomendações de saúde globais, isso pode desvalorizar a empresa e trazer prejuízos.

Ademais, podemos pensar também nas famílias dos funcionários e nas comunidades locais: por ser um vírus de alta transmissão, a vida delas também está sendo posta em risco aumentando as chances de contaminação.

\subsubsection{Relatório de Insustentabilidade}

Enquanto a Vale divulga em seu Relato Integrado o seu propósito de melhorar o futuro, e se parece transparente quanto às ações que está tomando para reparação dos desastres nas quais esteve envolvida, além de falar de seus outros investimentos em ações filantrópicas, uma organização internacional dos Atingidos e Atingidas pela Vale publicou o "Relatório de Insustentabilidade da Vale $2021 "$

O intuito desse relatório é justamente demonstrar a contradição dos números e ações que a Vale mostra, com o que eles pesquisam e coletam de informações sobre o que de fato está ocorrendo. 
Enquanto a Vale fala sobre o seu plano de enfrentamento à Covid na qual destinou mais de 109 milhões de dólares para diferentes frentes de atuação, além de alterar diversos atendimentos para remotos e paralisar operações próximas a populações de risco como as indígenas, o relatório de insustentabilidade levanta um ponto exatamente contrário: de que a vale "transformou crise em oportunidade".

Na visão deles, a Vale aproveitou o momento de pandemia para melhorar sua imagem e também ampliar seus lucros, e levanta diversos locais como Paraupebas no Pará, que vivenciaram surto de COVID por conta da operação da Vale, sem contar também com as condições dos funcionários, que também estiveram envolvidos, e sobre o descaso da Vale frente a isso, como foi visto com as práticas desleais com os funcionários, além de desrespeitar diversas normas sanitárias.

Outro ponto apresentado é sobre a reparação das áreas nas quais ocorreram os desastres, enquanto a Vale apresenta diversas ações e compromissos, a realidade é que continuam extremamente devastadas e sem auxílio ou compensação.

O relatório busca então verificar de fato o que está sendo de fato realizado pela organização e fazer a comparação com o que é publicado.

\subsection{0 uso das ferramentas de Responsabilidade Social Empresarial}

\subsubsection{Pacto Global}

A empresa Vale foi signatária do Pacto desde 2007, seguindo os dez princípios propostos, e por meio de um convite da ONU, a mineradora integra, desde 2010, na plataforma Global Compact Lead, que reúne empresas líderes em questões de sustentabilidade já engajadas na iniciativa do Pacto Global. Essa informação pode ser encontrada no site da empresa, no item "Parcerias institucionais".

No entanto, organizações globais de meio ambiente e direitos humanos pediram no dia 12 de fevereiro de 2019 que a Vale fosse excluída do Pacto Global, 
da Organização das Nações Unidas (ONU), após o rompimento da barragem em Brumadinho no dia 25 de janeiro de 2019, e inclusive, já não está mais na lista de empresas signatárias no site oficial do Pacto Global.

Essa denúncia aponta que a Vale falhou ao não avaliar adequadamente os riscos, ao deixar de tomar medidas preventivas e de mitigação e ao não adotar ações que evitassem a repetição de um desastre como o de Mariana, em 2015.

Nesse sentido, a mineradora teria violado uma série de direitos humanos e causado graves danos ambientais, o que fere os princípios do Pacto Global, prejudicando a imagem positiva, transparente e ética que a empresa sempre buscou passar ao público, incluindo em sua missão visão e valores.

Porém, segundo a empresa, ela segue se comprometendo com os princípios propostos, e focando na reparação integral dos impactos causados pelas tragédias, intensificando ainda mais seus compromissos não apenas com sustentabilidade, com a governança e transparência de suas ações sustentáveis, assim como com sua excelência operacional, mitigando riscos e gestão de ativos, além da saúde e segurança.

Além disso, a Vale está com ações ligadas ao 10 princípios, reafirmando o quanto vem trabalhado para conseguir novamente fazer parte da rede, também está engajado com o secretariado do Pacto Global anualmente, o qual ajuda a empresa a como enfrentar os desafios da sustentabilidade, pois os princípios propostos são mecanismos essenciais para orientar e guiar as empresas signatárias.

Em relação aos Direitos Humanos, o tema é abordado nos normativos da empresa, no Mapa Global Integrado de Riscos, além de no sistema de gestão (Vale Production System).

Também seguem o compromisso normativo ao abordar na Política Global de Direitos Humanos da VALE, criada em 2009 e revisada em 2019, reforçando o que a empresa apoia e respeita a proteção de direitos humanos, além de capacitar seus funcionários para serem agentes de Direitos; essa capacitação é obrigatório para todos os empregados desde 2021.

Para integrar os direitos humanos na companhia, a VALE inseriu normativos e frentes na sua área de gestão de riscos, gestão de fornecedores e 
segurança empresarial, além de outros processos decisórios da empresa, deixando-a presente em todas as fases do ciclo de vida dos empreendimentos.

Para o segundo princípio, de certificar-se que não são cúmplices de violações dos direitos humanos, as áreas de Direitos Humanos da Gerência Executiva de Gestão Social, Saúde \& Segurança, e Gestão Ambiental ajudam a identificar riscos em Direitos Humanos, elaborar e implementar controles preventivos e monitoramento. Ademais, existem uma Auditoria Interna e Ouvidoria.

Quando se fala de condições de trabalho, os princípios dizem que as empresas devem apoiar a liberdade de associação e o reconhecimento efetivo do direito à negociação coletiva, apoiar a eliminação de todas as formas de trabalho forçado ou compulsório, apoiar a efetiva erradicação do trabalho infantil e apoiar a igualdade de remuneração e a eliminação da discriminação no emprego.

Para isso, também na Política Global de Direitos Humanos ela se compromete em respeitar esses princípios, desde 2005 os empregados realizam uma eleição para votar no membro do Conselho de Administração e seus suplentes, conduzidas pela empresa em conjunto com os sindicatos. $97 \%$ da força de trabalho é realizada por acordos coletivos.

Sobre trabalho forçado e infantil, a Vale realiza análises de risco em seus novos fornecedores e exige a assinatura de cláusulas contratuais, além de também fazer parte da gestão de risco interna, em todas as fases do processo." A Vale informa em seu site que não houve registro ou denúncia envolvendo a empresa de ocorrência de trabalho análogo ao escravo ou infantil em nenhuma de suas operações.

Para apoiar a eliminação da discriminação com relação ao emprego a Vale possui políticas de remuneração compatíveis com a complexidade das funções e com o mercado de trabalho, além de se comprometer em respeitar e valorizar a diversidade, dando oportunidade pela meritocracia, inclusão, e não tolerar assédio de qualquer natureza. Até agosto de 2021 a Vale tinha 18\% de seus funcionários sendo mulheres, assim como 18\% na alta liderança. Em 2020 4,5\% do quadro de empregados era de pessoas com deficiência.

Quando se fala do Meio Ambiente, segundo o Pacto Global, as empresas devem apoiar uma abordagem preventiva aos desafios ambientais, desenvolver 
iniciativas para promover maior responsabilidade ambiental, incentivar 0 desenvolvimento e a difusão de tecnologias ambientalmente sustentáveis.

Como já visto nas práticas sustentáveis da Vale, ela direciona grande parte dos seus esforços para cumprir com essas 3 exigências do Pacto, acelerando os planos de reparação dos impactos, focando em evoluir seu sistema de barragens e monitorando e mitigando possíveis riscos, investindo em novas campanhas sustentáveis como da redução do consumo da água, conservação ambiental e diversas outras além de utilizar Inteligência Artificial em diversos ativos de sua ativação para aumentar e garantir a confiabilidade.

Por último, ao falar de anticorrupção, é necessário que as empresas combatam a corrupção em todas as suas formas, incluindo extorsão e suborno, e para garantir isso, todos os funcionários realizam treinamento sobre regras anticorrupção.

.A Vale atua em conformidade com as leis e regulamentações a que está sujeita, incluindo-se mas não se limitando à Lei 12.846/13 - Lei Anticorrupção brasileira, ao FCPA, U.S. Foreign Corrupt Practices Act e ao UK Bribery Act.

\subsubsection{Balanço Social}

Essa ferramenta é utilizada pela Vale já que, no Brasil, a elaboração e divulgação do Balanço Social passaram a ser obrigatório para as companhias abertas após o surgimento da Lei 11.638/07.

Dessa forma, é uma ferramenta que traz vantagens para a empresa, pois pode ser considerado um instrumento de amplificação do grau de confiança da sociedade na empresa, realçando as ações da mesma em prol da melhoria da sociedade e do meio ambiente, e também mostrando que o foco da empresa não é só o resultado lucrativo, mas também o resultado social devido a sua atuação socioambiental e valorização da cidadania corporativa, agregando valor e destaque para a marca e a imagem da empresa.

A Vale realiza o Balanço Social anual desde o ano de 2001. O Balanço Social da empresa é feito com um formato bem ilustrativo e luxuoso, causador de 
grande impacto visual. Ele pode ser encontrado no site da empresa, no item "relatórios anuais".

\subsubsection{Global Reporting Initiative (GRI)}

O Relatório de Sustentabilidade da empresa Vale é elaborado de acordo com as diretrizes da Global Reporting Initiative (GRI), com o objetivo de informar a sociedade as ações em prol do meio ambiente e das comunidades onde a empresa atua. Esses relatórios podem ser encontrados no site da Vale, no item "relatórios anuais - relatórios de sustentabilidade". No site, o primeiro relatório de sustentabilidade disponível é o do ano de 2006. Em cada relatório encontra se o "índice de conteúdo GRI”.

Em 2020, o Relatório de Sustentabilidade teve seu nome de Relato Integrado, para anunciar o novo propósito da empresa: "Existimos para melhorar e transformar o futuro juntos", contando com uma parte específica para Reparação, Covid-19, ESG, Governança, Ambiental e Social, e abordando também o econômica, falando sobre os três pilares do Tripé da Sustentabilidade.

Além do Relato Integrado publicado anualmente, a Vale também tem o Formulário de Referência, com informações das atividades, fatores de risco, finanças e outros, o Relatório de Administração, trazendo sobre a atuação da empresa e do Conselho, o Relatório de Transparência Fiscal e o Relatório Form 20-F, obrigatório para empresas estrangerias com ações nas bolsas dos EUA.

Em seus Relatos Integrados ela descreve os compromissos, com metas bem definidas do que pretende alcançar, até quando e como, além do que já alcançou e como conseguiu, trazendo grande expectativa sobre as ações futuras que a Vale irá implementar.

Assim como com o Pacto Global, no GRI a Vale também demonstra a preocupação de seguir os 11 princípios: transparência, inclusividade, auditabilidade, completude, relevância, contexto de sustentabilidade, exatidão, neutralidade, comparabilidade, clareza e conveniência. 
O Relato é extremamente complexo, com dados sobre pessoas indenizadas na reparação, e em qual período e valores investidos em cada ação de reparação, assim como as ações projetadas no Plano de Reparação.

Ao falar de Covid-19, também aborda as ações adotadas com os funcionários e sobre as doações realizadas, sempre com dados concretos.

Sobre a Estratégia ESG, eles priorizam falar sobre a gestão de riscos, medidas de prevenção e sobre criação de valor nas comunidades aos quais sua operação está presente.

É importante, para demonstrar o compromisso e seguir com as diretrizes da GRI, a cronologia apresentada, iniciando em 2017, com a meta estabelecida no momento, e a evolução até 2019, e depois até o final de 2020.

Em 2017 eles tinham encontrado 63 gaps em suas políticas ESG, até 2020 eles tinham eliminado 37 Gaps.

Também é citado suas ações de governança, como a nova política de remuneração, avaliação de desempenho, Diretoria Executiva e o Comitê de Auditoria, criado em 2020.

Em todos os tópicos são citados os compromissos para 2030, e os planos para alcançá-los, além de falar sempre das questões negativas tanto ambientais quanto sociais, e o que estão fazendo para combatê-las.

Percebe-se por esse Relato que a partir de 2017 a Vale começou a se estruturar internamente para conseguir se consolidar com uma imagem melhor no mercado, e vem atuando em diferentes frentes para isso, o Relato Integrado é uma delas, assim como a aderência às políticas ESG.

\subsubsection{SA8000}

Pelo fato de a Vale estar inserida no setor de mineração, ela não se enquadra nas organizações que podem receber essa certificação, contudo, não consta no relatório de "Certified Organizations" da Social Accontability International (SAI). Apesar disso, no relatório de sustentabilidade da Vale de 2016, disponível no site na aba de "relatórios anuais" a empresa afirmas que este segue as especificações da norma e a usa como referência, o que indicaria que ela tem 
uma preocupação com suas relações de trabalho internamente. Nos relatórios posteriores à 2016 essa referência não é citada. 


\section{Análise}

Nessa sessão foi feita a relação entre o referencial teórico e as práticas levantadas pela empresa.

\subsection{Vale e a Responsabilidade Socioambiental}

Ao analisar cada prática citada individualmente conseguimos entender melhor as motivações por trás das ações da empresa: vemos, nas práticas positivas da redução de água a empresa exercendo sua responsabilidade legal, que engloba as obrigações legais da empresa com as leis ambientais e se encaixa no cumprimento de normas e valores sustentáveis.

O fato de desenvolverem e programarem esses projetos, relacionados ao uso de água na atividade da empresa, o classifica como Responsabilidade Social Empresarial, pois se relaciona à operação principal da empresa, e traz benefício para sua própria produção e extração de minério.

Sobre as ações durante a pandemia, diferentemente das medidas de redução de água, essas ações não estão ligadas à atividade essencial da empresa, sendo assim classificadas como Ação Social Privada em seu cunho de voluntário e realizando doações pontuais. Logo, se enquadra no nível da Pirâmide de Carroll de responsabilidade filantrópica: a Vale está indo além de suas responsabilidades para com seus stakeholders e com o meio ambiente e usando seus recursos para ações positivas sociais no âmbito salubre, ajudando num período tão importante como o de crise.

Sabe-se porém, que a ação social privada de nada vale se a empresa não cumpre com os pilares da RSE, mas vamos entender um pouco mais sobre isso na análise das práticas negativas mais a diante. 
Assim como a conservação ambiental, classificada também na responsabilidade discricionária, tendo em vista seu caráter filantrópico. Essa prática da Vale também possui um comportamento voluntário de ajudar no ambiente, mesmo não sendo de obrigação legal ou caráter ético da empresa, já que não se relaciona com suas atividades ou locais que sua produção está instalada, por mais que a Vale tenha diversas áreas nas quais ela deveria atuar com a conservação ambiental, pois há muitos locais onde sua operação afeta o meio ambiente.

Quando vemos os problemas de gestão, primeiramente com as barragens, a empresa passou longe de qualquer conceito de responsabilidade legal, ética ou filantrópica ao negligenciar situações de risco, mostrando descaso com os afetados pelas tragédias e priorização da recuperação de lucros acima de tudo, além de claramente faltar com a Responsabilidade Social Empresarial.

No caso dos reassentamentos em Tetê a empresa Vale não cumpriu com a redução de impactos negativos de sua atividade na comunidade e no meio ambiente e se preocupou, somente, com uma gestão da qualidade do seu trabalho, deixando de lado a preocupação com toda a esfera afetada externamente, como a comunidade, não tendo um desenvolvimento social local.

Nesse sentido, a mineradora não manteve uma relação ética e transparente com todos os públicos com os quais ela se relaciona e não sustentou metas organizacionais que impulsionem o desenvolvimento sustentável da sociedade. Em relação à Pirâmide de Carroll, a descrição dessa prática pode ser abordada a partir da perspectiva, principalmente, econômica, assim como a prática menciona anteriormente, pois estas baseiam-se na tomada de medidas visando o aumento do valor da empresa, e um maior retorno financeiro.

O foco na terceira situação de problema de gestão citado segue o mesmo, percebe-se, mais uma vez, a falta de exercer sua Responsabilidade Social Empresarial em suas ações com os trabalhadores.

Por fim, relacionando com a pirâmide de Carroll, a prática adotada pela Vale está mais uma vez posicionada na base desta pirâmide, que é a Responsabilidade Econômica, consistindo em gerar lucro ao máximo, ser competitivo no mercado e eficiente. Assim, a empresa está mais focada em gerar um resultado econômico do que qualquer outra coisa, e não parar suas operações nem para garantir a 
segurança de seus funcionários, esquecendo-se de suas responsabilidades éticas.

É muito difícil validar todas as práticas positivas da Vale e comemorar os inúmeros benefícios que elas estão trazendo, se, simultaneamente, a própria empresa não está sendo capaz de cumprir com a sua palavra e não se preocupa com o seu próprio ambiente interno, com os seus funcionários e todos aqueles envolvidos diretamente nas consequências de suas operações, além do ambiente externo.

Como por exemplo, durante o período da pandemia, enquanto a organização adotou diversas Ações Sociais Privadas para ajudar na causa, ela também colocava os seus funcionários trabalhando em risco nas minas.

Ou como a Conservação Ambiental citada acima, se todos os esforços direcionados para essa ação voluntário estivessem na compensação ambiental nas áreas de Mariana e Brumadinho, teríamos uma outra realidade.

Conseguimos aqui relacionar ao conceito citado no Referencial Teórico de GreenWashing. O greenwashing traz justamente uma reflexão da motivação da empresa por trás das ações sociais e ambientais divulgadas, e se formos ver o por trás das práticas positivas e filantrópicas, muitas práticas que não condizem com o posicionamento e valores que a Vale divulga para seus stakeholders, o que pode ser considerado uma falta de transparência e um problema de governança.

\subsection{Greenwashing e ESG}

Como vimos no referencial, Greenwashing é o nome dado quando empresas promovem discursos e propagandas publicitárias ecologicamente sustentáveis, mas, na verdade, não promovem ações que realmente colaborem com a proteção do meio ambiente e dos impactos sociais relacionados à suas atividades.

Sendo assim, é justamente a propaganda enganosa, onde a realidade passada pelo marketing é completamente diferente da atuação efetiva da empresa.

Em relação ao que foi visto acima sobre a Vale e a comparação com a missão, visão e valores da Vale, com suas ações internas, vemos que elas não 
condizem com o apresentado e proposto pela organização, e que apenas algumas atitudes da empresa estão seguindo critérios sustentáveis.

As práticas positivas então vistas no presente trabalho podem se enquadrar como Greenwashing, uma vez que tentam desviar do público a atenção para os reais acontecimentos e práticas.

Essa classificação não invalida o bem que os investimentos positivos trazem, mas sim demonstram que, com tantos problemas de gestão e pessoas prejudicadas diretamente pela empresa, o marketing verde da Vale se torna uma forma de melhorar a imagem perante o mercado e passar uma mensagem de que estão sendo social e ambientalmente responsáveis, quando internamente ainda existem diversos problemas a serem resolvidos.

\subsection{Tripé da Sustentabilidade}

Quando vamos enquadrar a VALE no chamado "Tripé da Sustentabilidade", pela análise da empresa e principalmente pelos problemas de gestão acima citados, vemos que, apesar de serem detectados ambos os pilares no Relatório Integrado, entendemos que existe um foco muito grande no pilar econômico, e muitas das suas ações são baseadas nisso. Os problemas de gestão, inclusive, se deram pelo fato de que esse pilar foi priorizado, ao invés do ambiental e social.

Ao realizar a análise da Pirâmide de Caroll o foco na lucratividade ficou muito claro dentro da organização.

Contudo, como vimos, o tripé se baseia no equilíbrio entre as três dimensões, o que leva a empresa a deixar de olhar para o lado social e ambiental, demonstrando uma falta de Responsabilidade Socioambiental.

O desastre das barragens é uma prova disso, uma vez que após o primeiro rompimento, a Vale não realizou a revisão imediata das outras barragens, visto que havia um problema identificado; esse deveria ser o principal investimento, independentemente dos custos, quando ocorreu a tragédia. 


\subsection{Ferramentas da RSE}

Ao analisar as ferramentas da Responsabilidade Social Ambiental utilizadas pela Vale, fica mais uma vez claro que ela tem uma preocupação muito grande em se enquadrar nos modelos e padrões internacionais de sustentabilidade.

No Relatório ela aborda todos as diretrizes da GRI, conseguindo estruturar planos de ações e metas transparentes para reparação de dados e desenvolvimento sustentável interna e externamente.

Porém, mais uma vez vemos que apesar de seguir todos os princípios do Pacto Global, e atuar em todas as frentes com diversas ações diferentes, ela foi removida após a segunda tragédia da barragem, mostrando que independente das ações positivas que atua, permitir que ocorra pela segunda vez um impacto tão grande no ambiente fere de diversas maneiras a proposta deles de empresas responsáveis.

Vemos também o Relatório de Insustentabilidade, tentando de alguma forma desmascarar o Relato Integrado, apresentando fatos que desmentem os dados apresentados e comprovados, trazendo mais uma vez a percepção de que há um Greenwashing, e os dados negativos estão sendo mascarados pelas ações positivas da organização. 


\section{Conclusões e Sugestões}

A partir da análise do referencial teórico na prática da empresa Vale, vê-se de um lado um investimento muito forte em práticas sustentáveis positivas, porém, de outro, um descaso com os impactos que a sua operação gera.

É possível perceber o esforço da organização em adotar medidas de compensação ambiental, e sua constante busca social de reestabelecer sua imagem positiva perante seus stakeholders.

Sendo assim, nesse capítulo são apresentadas sugestões para tal, tendo em vista o objetivo do trabalho, de propor melhorias para a empresa.

\subsection{Reparação de danos}

Sendo assim, concluímos a importância de, antes de investir em Ação Social Privada, é preciso que a Vale faça uma mudança em sua Responsabilidade Social Empresarial, pondo primeiro em pauta todos aqueles que já foram afetados por suas ações no passado, como mostrado nos exemplos dos problemas de gestão: as famílias que não receberam indenização ou auxílio emergencial pelos danos causados em Mariana e Brumadinho, toda a área vegetal afetada pelo rompimento da barragem e os moradores da área de assentamento em Tete que não foram realocados para uma vida com boa qualidade e bem estar, além dos inúmeros não citados neste trabalho.

Essa deve ser a prioridade imediata da organização, investir $100 \%$ de seus recursos nessa reparação. Inclusive, é importante direcionar recursos que estão em outros projetos para conseguir concluir a reparação o mais rápido possível.

Isso é o mais importante pois foram pessoas afetadas diretamente pela organização, e muitas delas tiveram suas vidas arruinadas por conta das tragédias. Sendo assim, é de responsabilidade da VALE trabalhar para que isso seja corrigido e compensado. 
Após a correção de toda a consequência dos desastres anteriores, a Vale poderá pensar em aumentar suas ações sociais filantrópicas e voluntárias, como a conversação ambiental ou as doações durante a pandemia.

\subsection{Gestão de Risco}

A segunda pauta deverá ser investir recursos e garantir que sua operação não venha a ter mais nenhuma consequência ambiental e social. Para isso, a Vale deve programar um sistema eficaz de gestão sustentável, com equipes multifuncionais não somente em suas áreas administrativas, mas também onde ela opera e possui funcionários.

Atualmente, já existe um sistema de gestão de Risco que está voltado para isso, mas é primordial que ele atue em todo o ciclo de vida dos processos da empresa.

Essa pauta deverá englobar uma mudança no sistema de monitoramento de riscos, maior atenção para toda a situação dos funcionários, verificando se nenhum deles se encontra em situação de risco, contará com a contratação de especialistas para verificar a segurança de suas estruturas em escala global, desenvolverá sistemas de alerta efetivos e treinamento dos moradores das cidades próximas às suas barragens ou outros ambientes que envolvam riscos, além de direcionar equipes exclusivas para o monitoramento das atividades e recebimento e análise dos relatórios de riscos.

Também se sugere a de contratação de uma empresa terceirizada para fiscalizar todo o processo da empresa, com autonomia para tomar decisões que envolvam a melhora na relação com os interessados, evitando descaso por parte da empresa em práticas e projetos de significativa importância, como o risco do rompimento das barragens, visto que sem fiscalização a empresa não foi capaz de cumprir com seus valores e obrigações empresariais.

Aqui, não é necessário apenas um plano de ação para mitigar riscos, e sim uma equipe que monitore e acompanhe diariamente os processos, garantindo que todo o possível está sendo feito para que a VALE não tenha nenhuma falha, tanto em quesito ambiental com um possível desastre, tanto com o social, interno e externo, englobando todos os stakeholders da companhia. 
Por último, como visto no Relato Integrado a VALE já possui um plano de ação para conseguir identificar gaps na política ESG interna, e bolar planos para preenchê-los. Essa prática deve ser intensificada e acelerada nessa fase.

\subsection{Gestão de pessoas}

Além disso, quando se diz que a gestão de riscos não é apenas um fator que impacta nas consequências externas da operação da empresa, sejam estas ambientais ou sociais na área que atua, também é importante neste momento fazer uma análise interna.

Com isso, iremos entender como está a relação da organização com seus funcionários.

Incialmente, por parte do $\mathrm{RH}$ da empresa ao lado de uma consultoria terceirizada para realizar uma avaliação 360 com os funcionários.

Por mais que já tenha sido visto que a política de remuneração fora revista, existem diversos outros pontos que se enquadram nas condições de trabalho, e que iram impactar na felicidade do funcionário.

É necessário realizar entrevistas de desligamento com as pessoas que saíram da empresa e também passar formulários e solicitar feedbacks dos funcionários em todas as áreas da empresa, entendendo os pontos de melhoria e positivos, para conseguir atual em cima disso mudando o clima organizacional da empresa, e evitando com que as práticas desleais com os funcionários se repitam.

Com isso, iremos obter funcionários mais engajados com a empresa, mais motivados em mantê-la operando e defendendo os novos propósitos da VALE.

Isso não só irá alavancar a empresa internamente, mas irá também atrair e reter talentos no mercado, e, para isso é necessário investir também em um processo seletivo adequado, garantindo que as pessoas certas e alinhadas estarão sendo contratadas. 


\subsection{Ação Social Privada}

Dessa forma, com essas duas pautas concluídas, a Vale possuirá uma Gestão de Responsabilidade Social Empresarial, podendo assim entrar na pauta as Ações Sociais Privadas.

Elas não devem servir como uma compensação dos danos já causados pela empresa ou oportunidades de melhora na imagem da Vale, e sim serem adotadas após a correção de erros ocasionados pela atividade empresarial da empresa, que serão discutidos nas duas primeiras pautas.

As doações realizadas na pandemia, por exemplo, é uma ação que só deveria ser de preocupação da VALE caso as duas acima já estivessem concluídas, pois não é o momento para direcionar recursos para novos investimentos, quando existem reparações inacabadas e pessoas sofrendo por atividades da empresa.

Por mais que todas as ações sociais da VALE sejam de extrema importância e muito reconhecidas globalmente, chegará o momento para sua atuação, e este deve ser depois de realizar a reparação de todos os danos do passado e garantir um sistema eficaz que garanta e previna novos erros futuros.

Assim, então, poderá ser considerado que a Vale seja uma empresa socialmente e ambientalmente responsável, tendo um posicionamento de acordo com suas ações internas, visando todos os pilares da ESG e do Tripé, assim como investimentos em planos de desenvolvimento sustentável e ação filantrópicas. 


\section{Referências Bibliográficas}

A onda ESG e as armadilhas das práticas green, social e rainbow washing. Jornal Negócios, 24 agosto. 2021, ano XIX, n. 4.433.

AFONSO, R; BARTHOLO, R; FERREIRA; G SIMÕES, C; Responsabilidade social e Cidadania. Diálogo e responsabilidade Social. Rio de Janeiro, SESI, 2008

AFONSO, R; BARTHOLO, R; FERREIRA; G SIMÕES, C; Responsabilidade social e Cidadania. A construção da responsabilidade social. Rio de Janeiro, SESI, 2008

AFONSO, R; BARTHOLO, R; FERREIRA; G SIMÕES, C; Responsabilidade social e Cidadania. Normas e instrumentos de certificação da responsabilidade social empresarial Rio de Janeiro, SESI, 2008

ANGELO, M. Coronavírus: mesmo com empregados contaminados, Vale mantém operação e aglomerações em minas. The Intercept Brasil, Brasil, 26 mar. 2020. Disponível em: <https://theintercept.com/2020/03/26/coroavirus-valemantem-minas-operacao/>. Acesso em: 10 de setembro. 2021.

Atingidos pela Vale, Relatório de Insustentabilidade 2015, Brasil, 2015. Disponível em: <http://www.pacs.org.br/files/2015/04/Relatirio_pdf.pdf>. Acesso em: 10 de setembro. 2021.

BELÉM, F. Mina da Vale em Moçambique é criticada há quase cinco anos. RFI, Moçambique, 24 jan. 2016. Disponível em: <http://www.rfi.fr/br/africa/20160124-mina-da-vale-em-mocambique-e-criticadaha-quase-cinco-anos>. Acesso em: 15 de setembro. 2021.

BITTENCOURT, G. Brumadinho e Mariana: a dor que não passa. TV Brasil, Brasil, 21 jan. 2020. Disponível em: <https://tvbrasil.ebc.com.br/caminhos-dareportagem/2020/01/brumadinho-e-mariana-dor-que-nao-passa>. Acesso em: 27 de agosto. 2021.

BRAGA JR.; MARTINEZ, P.; CORREA, M.; MOURA-LEITE, C.; SILVA, D. Greenwashing effect, attitudes, and beliefs in green consumption, RAUSP Emerald Publishing Limited, vol. 54, n. 2, 2019.

BRASIL, A. Vale quitou multas em MG, mas não pagou Ibama e Ministério do Trabalho. Revista Exame, São Paulo: Abril, 25 jan. 2020. Disponível em: $<$ https://exame.abril.com.br/brasil/vale-quitou-multas-em-mg-mas-nao-pagouibama-e-ministerio-do-trabalho/>. Acesso em: 27 de agosto. 2021.

CALDAS, M. V. A.; VEIGA-NETO, A. R.; GUIMARÃES, L. G. A.; CASTRO, A. B. C.; PEREIRA, G. R. B. Greenwashing in environmental marketing strategy in the 
brazilian furniture market. Revista de Economia e Sociologia Rural, vol. 59, n. 3, 2021.

CALVI, P. Os quatro anos do rompimento da barragem de Mariana: balanço das violações de direitos humanos, Câmara dos Deputados, Brasília, 24 jan. 2019. Disponível em: <https://www2.camara.leg.br/atividadelegislativa/comissoes/comissoes-permanentes/cdhm/noticias/os-quatro-anos-dorompimento-da-barragem-de-mariana-balanco-das-violacoes-de-direitoshumanos>. Acesso em: 30 de agosto. 2021.

CAMPERA, F. Vale, exemplo mundial de incompetência e descaso, El País, São Paulo, 28 jan. 2019.2 Disponível em: $<$ https://brasil.elpais.com/brasil/2019/01/27/opinion/1548547908_087976.html>. Acesso em: 02 de setembro. 2021.

ESG nas instituições financeiras em 2021. Disponível em $<$ https://docplayer.com.br/204029765-Esg-nas-instituicoes-financeiras-fevereiro2021.html>. Acesso em: 02 de novembro. 2021.

FERNANDES, L.; SUDRÉ, L.; PINA; R. Histórico de violações da Vale vai muito além de Mariana e Brumadinho, Brasil de Fato, São Paulo, 29 jan. 2019. Disponível em: <https://www.brasildefato.com.br/2019/01/29/historico-deviolacoes-da-vale-vai-muito-alem-de-mariana-e-brumadinho>. Acesso em: 15 de setembro. 2021.

FILHO, C. Responsabilidade social e governança, Responsabilidade Social: as dimensões econômica, ética, legal e discricionária. Thomson, 2006.

GASPARETTO, V. Entrevista - Para além de Brumadinho e Mariana, a Vale em Moçambique. Portogente, Brasil, 24 mar. 2019. Disponível em: $<$ https://portogente.com.br/noticias/transporte-logistica/106159-vale-polui-econtamina-agua-solo-ar-e-alimentos-em-tete-mocambiques. Acesso em: 03 de setembro. 2021.

Global Reporting. Information, 2020. Disponível em: $<$ https://www.globalreporting.org/Pages/default.aspx>. Acesso em: 25 de setembro. 2021.

Pacto Global. Signatários. Brasil, 2020. Disponível em: <https://www.pactoglobal.org.br/ods_empresas>. Acesso em: 25 de setembro. 2021.

PASSARINHO, N. Tragédia em Brumadinho: As 5 lições ignoradas após tragédia de Mariana. BBC News Brasil, Londres, 01 fev. 2019. Disponível em: $<$ https://www.bbc.com/portuguese/brasil-47077083>. Acesso em: 15 de setembro. 2021.

PEREIRA, P. Reserva Natural Vale. Portal Educação, sem data. Disponível em: <https://siteantigo.portaleducacao.com.br/conteudo/artigos/turismo-ehotelaria/reserva-natural-vale/52592>. Acesso em: 15 de setembro. 2021.

\section{REUTERS. Organizações pedem exclusão da Vale do pacto Global da ONU.}

Exame, Brasil, 12 fev. 2019. Disponível em: $<$ https://exame.abril.com.br/brasil/organizacoes-pedem-exclusao-da-vale-dopacto-global-da-onu/>. Acesso em: 15 de setembro. 2021. 
SIMÕES, C. P.; FERREIRA; G.; AFONSO, R; BARTHOLO, R. Responsabilidade social e cidadania: conceitos e ferramentas. Brasília: Sesi, 2008.

UniEthos, Relatório de Sustentabilidade GRI Brasil, 2020. Disponível em: <http://www.uniethos.org.br/DesktopDefault.aspx?TabID=3704\&Alias=Uniethos\& Lang=pt-BR $>$. Acesso em: 30 de agosto. 2021.

VALE, Água. $\quad 2020 . \quad$ Disponível em: $<$ http://www.vale.com/esg/pt/Paginas/Agua.aspx>. Acesso em: 25 de agosto. 2021.

VALE, Desafio COVID-19: Vale recebe mais de 1450 propostas para reduzir os impactos dos vírus na sociedade. Brasil, 2020. Disponível em: <http://www.vale.com/brasil/PT/aboutvale/news/Paginas/Desafio-COVID-19Vale-recebe-mais-de-1-450-propostas-para-reduzir-os-impactos-do-virus-nasociedade.aspx>. Acesso em: 30 de agosto. 2021.

VALE, Missão, Visão e Valores. Brasil, 2020. Disponível em: $<$ http://www.vale.com/brasil/PT/aboutvale/mission/Paginas/default.aspx>. Acesso em: 25 de agosto. 2021.

VALE, Nossos Compromissos. Brasil, 2020. Disponível em: <http://www.vale.com/brasil/>. Acesso em: 25 de agosto. 2021.

VALE, Parcerias Institucionais. Brasil, 2020. Disponível em: $<$ http://www.vale.com/brasil/PT/aboutvale/institutional-

partnerships/Paginas/default.aspx>. Acesso em: 25 de agosto. 2021.

VALE, Relatórios Anuais. Brasil, 2020. Disponível em: $<$ http://www.vale.com/brasil/PT/investors/information-market/annualreports/Paginas/default.aspx>. Acesso em: 25 de agosto. 2021.

VALE, Relatórios de Sustentabilidade. Brasil, 2020. Disponível em: $<$ http://www.vale.com/brasil/PT/investors/information-market/annualreports/sustainability-reports/Paginas/default.aspx>. Acesso em: 25 de agosto. 2021. 